\title{
Corni Fructus: a review of chemical constituents and pharmacological activities
}

\author{
Yu Dong ${ }^{1}$, Zhe-Ling Feng ${ }^{1}$, Hu-Biao Chen ${ }^{2}$, Fu-Sheng Wang ${ }^{3}$ and Jia-Hong Lu ${ }^{1 *}$ (])
}

\begin{abstract}
Cornus officinalis Sieb. et Zucc. is part of the genus Cornus of the family Cornaceae. Ripening and dry fruits (Corni Fructus) are recognized as an essential herb medicine in the traditional Chinese medicine (TCM) and have been widely used for over 2000 years. This review provides a comprehensive summary of Corni Fructus (CF), including the botany, phytochemistry, traditional use, and current pharmacological activities. According to the basic theory of TCM, CF usually participates in various Chinese medicinal formulae to exert the essential roles in replenishing liver and kidney, arresting seminal emission and sweat. Based on modern pharmacological studies, about 90 compounds have been isolated and identified from CF. In vivo and in vitro experimental studies indicate that CF exhibits extensive pharmacological activities including hypoglycemic, antioxidant, anti-inflammatory, anticancer, neuroprotective, hepatoprotective, and nephroprotective activities. However, only about $18 \%$ of chemical constituents in CF were tested. It means the potential pharmacological activities and clinical values of CF need to be further investigated.
\end{abstract}

Keywords: Cornus officinalis Sieb. et Zucc., Corni Fructus, Shan Zhu Yu, Phytochemistry, Pharmacological activity

\section{Background}

Cornus officinalis Sieb. et Zucc., commonly known as Shan Zhu Yu/山茱英 (in Chinese), Asiatic Dogwood, and Japanese Cornel Dogwood, is a deciduous shrub or dungarunga in the genus Cornus (family Cornaceae). It is a heliophilous plant that grows in the warm-temperate zone. The most suitable growth temperature is between 20 and $30^{\circ} \mathrm{C}$, it also has a specific cold resistance that can temporarily grow in $-18{ }^{\circ} \mathrm{C}$ low-temperature zone. Cornus officinalis Sieb. et Zucc. can be found in Anhui, Gansu, Jiangsu, Jiangxi, Shandong, Shanxi in China, Korea, and Japan. It usually grows in 400-1500 m high mountain slope, forest or forest edge. Ripening fruits are picked during September and October and dried in the air for medical uses [1, 2].

About 2200 years ago, Cornus officinalis Sieb. et Zucc. fructus (usually known as Corni Fructus) was first recorded in Shen Nong's Materia Medica (Fig. 1).

\footnotetext{
*Correspondence: jiahonglu@umac.mo

${ }^{1}$ State Key Laboratory of Quality Research in Chinese Medicine, Institute of Chinese Medical Sciences, University of Macau, Room 7015, N22, Avenida da Universidade, Taipa, Macau SAR, People's Republic of China Full list of author information is available at the end of the article
}

According to the basic theory of TCM, CF is characterized as replenishing liver and kidney, arresting seminal emission and sweat for its sour, astringent, and tepid properties [1]. It is used to treat four series of clinical symptoms. The first part of symptoms contains vertigo, tinnitus, weakness of the waist and knees which are caused by liver and kidney deficiency. CF is usually combined with Radix Rehmanniae Praeparata, Dioscoreae Rhizoma, Alismatis Rhizoma, Moutan Cortex, Poria to make Liuwei Dihuang Wan (六味地黄丸) replenish liver and kidney Yin [3]. For patients with kidney Yang deficiency, CF helps Cinnamomi Cortex, Aconiti Lateralis Radix Praeparata to reinforce Yang from Yin, e.g., Jingui Shenqi Wan (金贵肾气丸) [4]. The second part of symptoms contains spermatorrhoea and polydipsia. For patients with kidney deficiency, CF is frequently used with Radix Rehmanniae Praeparata, Dioscoreae Rhizoma, Cervi Cornu Pantotrichum, Psoraleae Fructus. For patients with dysfunction of the urinary bladder, CF is often applied with Mantidis Oötheca, Rubi Fructus, Rosae Laevigatae Fructus. The third part of symptom contains hypermenorrhea. CF is usually combined with Radix Rehmanniae Praeparata, Angelica Sinensis, Radix Paeoniae Alba to make Guchong Tang (固冲汤) preserve

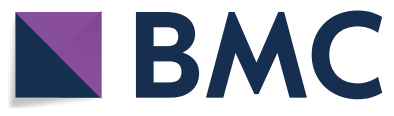

(c) The Author(s) 2018. This article is distributed under the terms of the Creative Commons Attribution 4.0 International License (http://creativecommons.org/licenses/by/4.0/), which permits unrestricted use, distribution, and reproduction in any medium, provided you give appropriate credit to the original author(s) and the source, provide a link to the Creative Commons license, and indicate if changes were made. The Creative Commons Public Domain Dedication waiver (http://creativecommons.org/ publicdomain/zero/1.0/) applies to the data made available in this article, unless otherwise stated. 

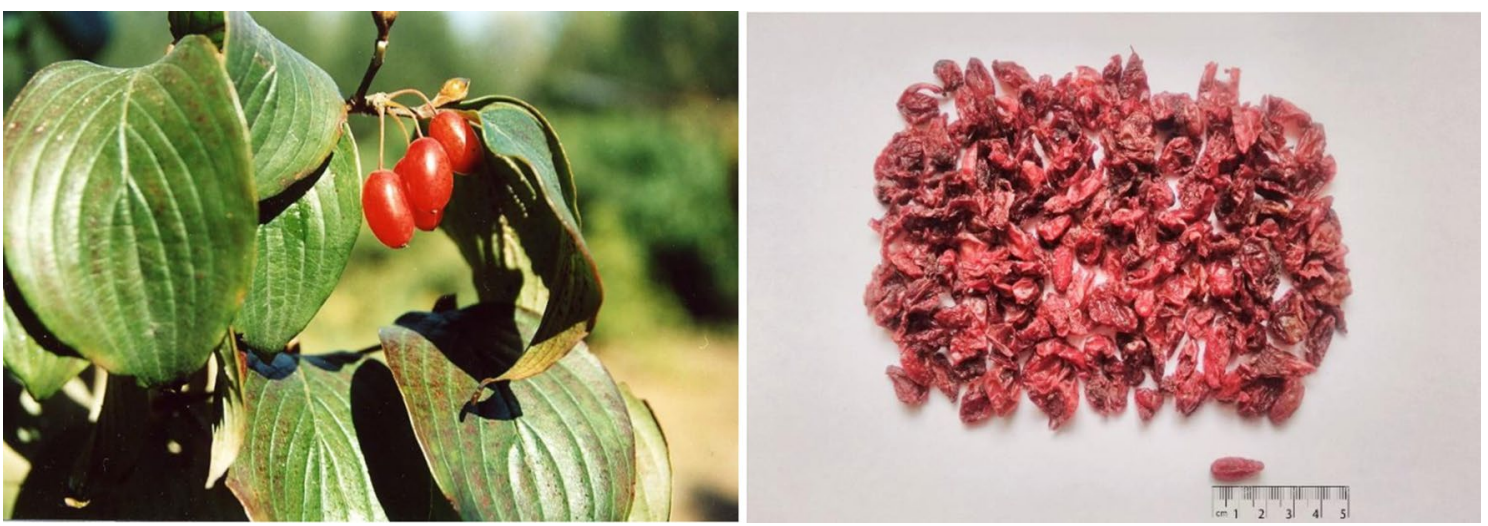

Fig. 1 Corni Fructus: a crude fruits, $\mathbf{b}$ processed fruits

Primordial Qi and stop Blood [5]. The fourth part of symptoms contains profuse cold sweating, pale complexion, cold limbs, and a feeble pulse. For patients with the Yang depletion syndrome, Ginseng Radix et Rhizoma, Aconiti Lateralis Radix Praeparata, and CF are applied in Laifu Tang (来复汤) to restore Yang from collapse. Medical practices indicate that CF can be combined with either Yin-tonifying or Yang-invigorating herbs to act as the sovereign drug or adjuvant drug in Chinese medicinal formulae and treat different types of TCM syndromes. Besides, CF is primarily made into the honey bolus to treat chronic diseases while is usually made into the decoction to treat acute conditions.

\section{Chemical constituents}

About 90 compounds have been isolated and identified from CF, including terpenoids, flavonoids, tannins, polysaccharides, phenylpropanoids, sterols, carboxylic acids, furans, and mineral substances. Chemical constituents are listed in Table 1. Among them, iridoids, tannins, and flavonoids are the major components. Their chemical structures are shown in Figs. 2, 3, 4 and 5.

\section{Terpenoids (1-26) and flavonoids (27-39)}

Most terpenoids and flavonoids in CF shared two similar isolation processes. Firstly, CF was percolated with ethanol to acquire the solvent which was then evaporated under reduced pressure. The resulting extract was suspended in water and then partitioned with ethyl acetate for several times. Finally, the extract was subjected to column chromatography over silica gel to yield compounds. Secondly, CF was grounded into powder and then subjected to supercritical carbon dioxide to yield extract. The resulting extract was subjected to GC-MS to identify the chemical components. So far, 26 terpenoids and 13 flavonoids have been isolated and identified from
CF. Among terpenoids, the pharmacological activities of sweroside (1), loganin (5), cornuside (23), ursolic acid (24), and oleanolic acid (25) have been further assayed, and a wide range of pharmacological activities has been revealed. Furthermore, two types of flavonoids namely kaempferol (28), quercetin (33), and their derivatives are the essential flavonoids.

\section{Tannins (40-69)}

During the isolation process, CF was firstly homogenized in acetone and then filtered to acquire an aqueous solution which was sequentially extracted with diethyl ether and ethyl acetate. The extract was subjected to column chromatography to give compounds. Finally, the chemical structure and molecular weight were determined using nuclear magnetic resonance (NMR) spectroscopy. To date, 30 tannic acids have been isolated from CF. Tsutomu HATANO identified 28 of them. Many tannic acids in this Chinese herb have the large molecular weight, e.g., the molecular weight of Cornusiins $\mathrm{A}-\mathrm{F}$ and Camptothins $\mathrm{A}-\mathrm{B}$ are even larger than $1000 \mathrm{Da}[6,7]$, because dimers and trimers exist in these types of tannic acids.

\section{Polysaccharides (70-79)}

Wu and Yin identified most polysaccharides in CF $[8,9]$. In their isolation process, hot water or petroleum ether was initially used for combining with assistant ultrasonic and microwave to break the cell wall to isolate polysaccharides. Further separation and purification were achieved by the combination of several techniques, e.g., fractional precipitation, ethanol precipitation, ionexchange chromatography and affinity chromatography. Finally, infrared spectroscopy analysis and morphological analysis were used to determine the physiochemical and structural features of the polysaccharide. 
Table 1 Chemical constituents identified from CF

\begin{tabular}{|c|c|c|c|c|c|}
\hline No. & Chemical class & Compound name & Chemical formula & Exact mass & References \\
\hline & \multicolumn{5}{|l|}{ Terpenoids } \\
\hline 1 & \multirow[t]{19}{*}{ Iridoids } & Sweroside & $\mathrm{C}_{16} \mathrm{H}_{22} \mathrm{O}_{9}$ & 358.1264 & {$[73]$} \\
\hline 2 & & Loganic acid & $\mathrm{C}_{16} \mathrm{H}_{24} \mathrm{O}_{10}$ & 376.1369 & [19] \\
\hline 3 & & Cornin & $\mathrm{C}_{17} \mathrm{H}_{24} \mathrm{O}_{10}$ & 388.1369 & {$[73]$} \\
\hline 4 & & 7-Dehydrologanin & $\mathrm{C}_{17} \mathrm{H}_{24} \mathrm{O}_{10}$ & 388.1369 & {$[74]$} \\
\hline 5 & & Loganin & $\mathrm{C}_{17} \mathrm{H}_{26} \mathrm{O}_{10}$ & 390.1526 & {$[74]$} \\
\hline 6 & & 7-a-Morroniside & $\mathrm{C}_{17} \mathrm{H}_{26} \mathrm{O}_{11}$ & 406.1475 & {$[75]$} \\
\hline 7 & & 7- $\beta$-Morroniside & $\mathrm{C}_{17} \mathrm{H}_{26} \mathrm{O}_{11}$ & 406.1475 & {$[75]$} \\
\hline 8 & & 7-a-O-Methyl-morroniside & $\mathrm{C}_{18} \mathrm{H}_{28} \mathrm{O}_{11}$ & 420.1632 & {$[75]$} \\
\hline 9 & & 7- $\beta$-O-Methyl-morroniside & $\mathrm{C}_{18} \mathrm{H}_{28} \mathrm{O}_{11}$ & 420.1632 & {$[75]$} \\
\hline 10 & & 7-a-O-Ethyl-morroniside & $\mathrm{C}_{18} \mathrm{H}_{29} \mathrm{O}_{11}$ & 421.1710 & {$[75]$} \\
\hline 11 & & 7- $\beta$-O-Ethyl-morroniside & $\mathrm{C}_{18} \mathrm{H}_{29} \mathrm{O}_{11}$ & 421.1710 & {$[75]$} \\
\hline 12 & & 7-a-O-Butyl-morroniside & $\mathrm{C}_{21} \mathrm{H}_{34} \mathrm{O}_{11}$ & 462.2101 & {$[43]$} \\
\hline 13 & & 7- $\beta$-O-Dimethyl-butanedioate morroniside & $\mathrm{C}_{23} \mathrm{H}_{34} \mathrm{O}_{15}$ & 550.1898 & {$[76]$} \\
\hline 14 & & Logmalicids A & $\mathrm{C}_{21} \mathrm{H}_{29} \mathrm{O}_{14}$ & 505.1557 & {$[24]$} \\
\hline 15 & & Logmalicids B & $\mathrm{C}_{21} \mathrm{H}_{29} \mathrm{O}_{14}$ & 505.1557 & {$[24]$} \\
\hline 16 & & Cornusfuroside A & $\mathrm{C}_{25} \mathrm{H}_{34} \mathrm{O}_{13}$ & 542.1999 & {$[77]$} \\
\hline 17 & & Cornusfuroside B & $\mathrm{C}_{25} \mathrm{H}_{34} \mathrm{O}_{13}$ & 542.1999 & {$[77]$} \\
\hline 18 & & Cornusfuroside $\mathrm{C}$ & $\mathrm{C}_{25} \mathrm{H}_{34} \mathrm{O}_{13}$ & 542.1999 & {$[77]$} \\
\hline 19 & & Cornusfuroside D & $\mathrm{C}_{29} \mathrm{H}_{34} \mathrm{O}_{15}$ & 622.1898 & {$[77]$} \\
\hline 20 & \multirow[t]{4}{*}{ Secoiridoids } & Linalool & $\mathrm{C}_{10} \mathrm{H}_{18} \mathrm{O}$ & 154.1358 & {$[78]$} \\
\hline 21 & & Linalool oxide & $\mathrm{C}_{10} \mathrm{H}_{18} \mathrm{O}_{2}$ & 170.1307 & {$[79]$} \\
\hline 22 & & Secoxyloganin & $\mathrm{C}_{17} \mathrm{H}_{24} \mathrm{O}_{11}$ & 404.1319 & {$[24]$} \\
\hline 23 & & Cornuside & $\mathrm{C}_{24} \mathrm{H}_{30} \mathrm{O}_{14}$ & 542.1636 & {$[74]$} \\
\hline 24 & \multirow[t]{3}{*}{ Triterpenoids } & Ursolic acid & $\mathrm{C}_{30} \mathrm{H}_{48} \mathrm{O}_{3}$ & 456.3603 & {$[74]$} \\
\hline 25 & & Oleanolic acid & $\mathrm{C}_{30} \mathrm{H}_{48} \mathrm{O}_{3}$ & 456.3603 & {$[15]$} \\
\hline 26 & & Arjunglucoside II & $\mathrm{C}_{36} \mathrm{H}_{58} \mathrm{O}_{10}$ & 650.4030 & {$[74]$} \\
\hline & \multicolumn{5}{|l|}{ Flavonoids } \\
\hline 27 & & Naringenin & $\mathrm{C}_{15} \mathrm{H}_{12} \mathrm{O}_{5}$ & 272.0685 & {$[74]$} \\
\hline 28 & & Kaempferol & $\mathrm{C}_{15} \mathrm{H}_{10} \mathrm{O}_{6}$ & 286.0477 & {$[79]$} \\
\hline 29 & & Kaempferide & $\mathrm{C}_{16} \mathrm{H}_{12} \mathrm{O}_{6}$ & 300.0634 & {$[80]$} \\
\hline 30 & & Kaempferol-3-O- $\beta$-D-galactopyranoside & $\mathrm{C}_{21} \mathrm{H}_{20} \mathrm{O}_{11}$ & 448.1006 & {$[24]$} \\
\hline 31 & & Kaempferol-3-O- $\beta$-D-glucoside & $\mathrm{C}_{21} \mathrm{H}_{20} \mathrm{O}_{11}$ & 448.1006 & {$[74]$} \\
\hline 32 & & Kaempferol-3-O- $\beta$-D-rutinoside & $\mathrm{C}_{27} \mathrm{H}_{30} \mathrm{O}_{15}$ & 594.1585 & {$[24]$} \\
\hline 33 & & Quercetin & $\mathrm{C}_{15} \mathrm{H}_{10} \mathrm{O}_{7}$ & 302.0427 & {$[79]$} \\
\hline 34 & & Quercetin-3-O- $\beta$-D-galactopyranoside & $\mathrm{C}_{21} \mathrm{H}_{20} \mathrm{O}_{12}$ & 464.0955 & {$[24]$} \\
\hline 35 & & Quercetin-3-O- $\beta$-D-glucuronide & $\mathrm{C}_{21} \mathrm{H}_{18} \mathrm{O}_{13}$ & 478.0747 & {$[24]$} \\
\hline 36 & & Quercetin-3-O- $\beta$-D-glucuronide methyl ester & $\mathrm{C}_{22} \mathrm{H}_{20} \mathrm{O}_{13}$ & 492.0904 & {$[24]$} \\
\hline 37 & & Quercetin-3-O- $\beta$-D-(6-n-butyl glucuronide) & $\mathrm{C}_{25} \mathrm{H}_{25} \mathrm{O}_{13}$ & 533.1295 & {$[15]$} \\
\hline 38 & & (-)-Epicatechin-3-O-gallate & $\mathrm{C}_{22} \mathrm{H}_{18} \mathrm{O}_{10}$ & 442.0900 & {$[15]$} \\
\hline 39 & & Isoquercitrin & $\mathrm{C}_{21} \mathrm{H}_{20} \mathrm{O}_{12}$ & 464.0955 & {$[80]$} \\
\hline
\end{tabular}


Table 1 (continued)

\begin{tabular}{|c|c|c|c|c|c|}
\hline No. & Chemical class & Compound name & Chemical formula & Exact mass & References \\
\hline & Tannins & & & & \\
\hline 40 & & Gallic acid & $\mathrm{C}_{7} \mathrm{H}_{6} \mathrm{O}_{5}$ & 170.0215 & [74] \\
\hline 41 & & 7-O-Galloyl-D-sedoheptulose & $\mathrm{C}_{14} \mathrm{H}_{18} \mathrm{O}_{11}$ & 362.0849 & [19] \\
\hline 42 & & Gemin D & $\mathrm{C}_{27} \mathrm{H}_{22} \mathrm{O}_{18}$ & 634.0806 & {$[6,7]$} \\
\hline 43 & & Oenothein C & $\mathrm{C}_{34} \mathrm{H}_{24} \mathrm{O}_{22}$ & 784.0759 & {$[6,7]$} \\
\hline 44 & & 3-O-Galloyl-d-glucose & $\mathrm{C}_{13} \mathrm{H}_{16} \mathrm{O}_{10}$ & 332.0743 & {$[6,7]$} \\
\hline 45 & & 2,3-Di-O-galloyl-d-glucose & $\mathrm{C}_{20} \mathrm{H}_{20} \mathrm{O}_{14}$ & 484.0853 & {$[6,7]$} \\
\hline 46 & & 1,2,3-Tri-O-galloyl- $\beta$-D-glucose & $\mathrm{C}_{27} \mathrm{H}_{24} \mathrm{O}_{18}$ & 636.0963 & {$[6,7]$} \\
\hline 47 & & 1,2,6-Tri-O-galloyl- $\beta$-D-glucose & $\mathrm{C}_{27} \mathrm{H}_{24} \mathrm{O}_{18}$ & 636.0963 & {$[6,7]$} \\
\hline 48 & & 1,2,3,6-Tetra-O-galloyl- $\beta$-D-glucose & $\mathrm{C}_{34} \mathrm{H}_{28} \mathrm{O}_{22}$ & 788.1072 & {$[6,7]$} \\
\hline 49 & & Tellimagrandin I & $\mathrm{C}_{34} \mathrm{H}_{26} \mathrm{O}_{22}$ & 786.0916 & {$[6,7]$} \\
\hline 50 & & Tellimagrandin II & $\mathrm{C}_{41} \mathrm{H}_{30} \mathrm{O}_{26}$ & 938.1025 & {$[6,7]$} \\
\hline 51 & & Isocoriariin F & $\mathrm{C}_{34} \mathrm{H}_{26} \mathrm{O}_{23}$ & 802.0865 & {$[6,7]$} \\
\hline 52 & & Coriariin F & $\mathrm{C}_{34} \mathrm{H}_{26} \mathrm{O}_{23}$ & 802.0865 & {$[6,7]$} \\
\hline 53 & & Rugosin B & $\mathrm{C}_{41} \mathrm{H}_{30} \mathrm{O}_{27}$ & 954.0974 & {$[6,7]$} \\
\hline 54 & & Isorugosin B & $\mathrm{C}_{41} \mathrm{H}_{30} \mathrm{O}_{27}$ & 954.0974 & {$[6,7]$} \\
\hline 55 & & Isoterchebin & $\mathrm{C}_{41} \mathrm{H}_{30} \mathrm{O}_{27}$ & 954.0974 & {$[6,7]$} \\
\hline 56 & & Isorugosin A & $\mathrm{C}_{48} \mathrm{H}_{34} \mathrm{O}_{31}$ & 1106.1084 & {$[6,7]$} \\
\hline 57 & & Rugosin D & $\mathrm{C}_{82} \mathrm{H}_{58} \mathrm{O}_{52}$ & 1874.1894 & {$[6,7]$} \\
\hline 58 & & Isorugosin D & $\mathrm{C}_{82} \mathrm{H}_{58} \mathrm{O}_{52}$ & 1874.1894 & {$[6,7]$} \\
\hline 59 & & Camptothin A & $\mathrm{C}_{61} \mathrm{H}_{46} \mathrm{O}_{40}$ & 1418.1565 & {$[6,7]$} \\
\hline 60 & & Camptothin B & $\mathrm{C}_{75} \mathrm{H}_{54} \mathrm{O}_{48}$ & 1722.1785 & {$[6,7]$} \\
\hline 61 & & Cornusiin B & $\mathrm{C}_{48} \mathrm{H}_{30} \mathrm{O}_{30}$ & 1086.0822 & {$[6,7]$} \\
\hline 62 & & Cornusiin A & $\mathrm{C}_{68} \mathrm{H}_{50} \mathrm{O}_{44}$ & 1570.1675 & {$[6,7]$} \\
\hline 63 & & Cornusiin D & $\mathrm{C}_{75} \mathrm{H}_{54} \mathrm{O}_{48}$ & 1722.1785 & {$[6,7]$} \\
\hline 64 & & Cornusiin E & $\mathrm{C}_{82} \mathrm{H}_{58} \mathrm{O}_{52}$ & 1874.1894 & {$[6,7]$} \\
\hline 65 & & Cornusiin $\mathrm{F}$ & $\mathrm{C}_{95} \mathrm{H}_{70} \mathrm{O}_{62}$ & 2202.2325 & {$[6,7]$} \\
\hline 66 & & Cornusiin C & $\mathrm{C}_{102} \mathrm{H}_{74} \mathrm{O}_{66}$ & 2354.2434 & {$[6,7]$} \\
\hline 67 & & Methyl tri-O-methylgallate & $\mathrm{C}_{11} \mathrm{H}_{14} \mathrm{O}_{5}$ & 226.0841 & {$[6,7]$} \\
\hline 68 & & Dimethyl hexamethoxydiphenate & $\mathrm{C}_{22} \mathrm{H}_{26} \mathrm{O}_{10}$ & 450.1526 & {$[6,7]$} \\
\hline \multirow[t]{2}{*}{69} & & Trimethyl-octa-O-methylvaloneate & $\mathrm{C}_{32} \mathrm{H}_{36} \mathrm{O}_{15}$ & 660.2054 & {$[6,7]$} \\
\hline & Polysaccharides & & & & \\
\hline 70 & & Co-4 & & & {$[8]$} \\
\hline 71 & & COP-1 & & & [9] \\
\hline 72 & & COP-2 & & & [9] \\
\hline 73 & & COP-3 & & & [9] \\
\hline 74 & & COP-4 & & & {$[9]$} \\
\hline 75 & & FCAP1 & & & {$[81]$} \\
\hline 76 & & FCP5-A & & & [8] \\
\hline 77 & & PFCA-III & & & [8] \\
\hline 78 & & PFCC-I & & & [8] \\
\hline \multirow[t]{2}{*}{79} & & SZYP-2 & & & [8] \\
\hline & Other compounds & & & & \\
\hline 80 & Phenylpropanoids & p-Hydroxycinnamic acid & $\mathrm{C}_{9} \mathrm{H}_{8} \mathrm{O}_{3}$ & 164.0473 & [74] \\
\hline 81 & & Caffeic acid & $\mathrm{C}_{9} \mathrm{H}_{8} \mathrm{O}_{4}$ & 180.0423 & [15] \\
\hline 82 & & Caftaric acid monomethyl ester & $\mathrm{C}_{14} \mathrm{H}_{14} \mathrm{O}_{9}$ & 326.2556 & [15] \\
\hline 83 & & Caffeoyltartaric acid dimethyl ester & $\mathrm{C}_{15} \mathrm{H}_{16} \mathrm{O}_{9}$ & 340.0794 & {$[76]$} \\
\hline 84 & Sterols & $\beta$-Sitosterol & $\mathrm{C}_{29} \mathrm{H}_{50} \mathrm{O}$ & 414.7067 & [15] \\
\hline 85 & & Daucosterol-6'-malate & $\mathrm{C}_{39} \mathrm{H}_{64} \mathrm{O}_{10}$ & 692.4499 & {$[80]$} \\
\hline
\end{tabular}


Table 1 (continued)

\begin{tabular}{|c|c|c|c|c|c|}
\hline No. & Chemical class & Compound name & Chemical formula & Exact mass & References \\
\hline 86 & Carboxylic acids & Succinic acid & $\mathrm{C}_{4} \mathrm{H}_{6} \mathrm{O}_{4}$ & 118.0266 & [85] \\
\hline 87 & & Malic acid & $\mathrm{C}_{4} \mathrm{H}_{6} \mathrm{O}_{5}$ & 134.0215 & [85] \\
\hline 88 & & Methylmalic acid & $\mathrm{C}_{5} \mathrm{H}_{8} \mathrm{O}_{5}$ & 148.0372 & [74] \\
\hline 89 & & Citric acid & $\mathrm{C}_{6} \mathrm{H}_{8} \mathrm{O}_{7}$ & 192.0270 & [85] \\
\hline 90 & & Butoxysuccinic acid & $\mathrm{C}_{8} \mathrm{H}_{14} \mathrm{O}_{5}$ & 190.1938 & [15] \\
\hline 91 & Furans & 5-Hydroxymethylfurfural & $\mathrm{C}_{6} \mathrm{H}_{6} \mathrm{O}_{3}$ & 126.0317 & [73] \\
\hline 92 & & Dimethyltetrahydrofuran cis-2,5-dicarboxylate & $\mathrm{C}_{8} \mathrm{H}_{12} \mathrm{O}_{5}$ & 188.0685 & [79] \\
\hline 93 & Mineral substances & $\mathrm{Ca}, \mathrm{Fe}, \mathrm{K}, \mathrm{Mg}, \mathrm{Mn}, \mathrm{Zn}$ & & & [82] \\
\hline
\end{tabular}

\section{Other compounds (80-93)}

Four phenylpropanoids, two sterols, five carboxylic acids, two furans, and several mineral substances have also been determined. Among them, 5-hydroxymethylfurfural exhibits diverse biological activities. Besides, Chen, $\mathrm{Li}$, and Wen identified 32,16 , and 48 volatile compounds by GC-MS, respectively [10-12].

\section{Pharmacological activities}

Although just a few chemical constituents from CF are assayed for their biological activities, these components displayed diverse pharmacological activities. Detailed biological activities are summarized in Table 2 .

\section{Hypoglycemic activity and diabetic target organs protective activity}

Diabetes mellitus (DM) is a group of long-term and chronic metabolic disorders which are associated with high serum glucose levels. Compared with the no treatment diabetic animal model group, CF extract (at $300 \mathrm{mg} \mathrm{kg}^{-1} 2 \mathrm{day}^{-1}$ and $400 \mathrm{mg} \mathrm{kg}^{-1} \mathrm{day}^{-1}$ p.o.), loganin, morroniside, and ursolic acid (each at $200 \mathrm{mg} \mathrm{kg}^{-1} \mathrm{day}^{-1}$ p.o.) for 4 weeks can significantly decrease fasting blood glucose and alleviate polyphagia, polydipsia, polyuria, and weight loss [13, 14]. In He's study, metformin (at $200 \mathrm{mg} \mathrm{kg}^{-1}$ day $^{-1}$ p.o.) demonstrated better effect [14]. Besides, loganin, morroniside, ursolic acid, and butyl morroniside (each at $100 \mu \mathrm{mol} \mathrm{L}{ }^{-1}$ ) can protect the pancreatic $\beta$-cells from high glucose-induced excessive oxidative stress and apoptosis $[14,15]$, may further increase the insulin release. Compared with the insulin treatment, CF extract, (-)-epicatechin-3-O-gallate, and caftaric acid monomethyl ester (each at $50 \mu \mathrm{mol} \mathrm{L}^{-1}$ ) can also significantly inhibit $\alpha$-glucosidase activity to slow down the elevation of serum glucose levels $[14,16,17]$ and suppress the hepatic gluconeogenesis by decreasing the protein and mRNA levels of PEPCK in vitro $[15,18]$.

Also, CF extract, iridoid glycosides, and the single compound can decrease $24 \mathrm{~h}$ urine protein and serum levels of urea nitrogen and creatinine. To be specific, loganin, morroniside, and 7-O-galloyl-D-sedoheptulose (each at $20-100 \mathrm{mg} \mathrm{kg}^{-1} \mathrm{day}^{-1}$ p.o.) for 10 days and 8 weeks can significantly inhibit both AGE/RAGE formation [19-22] and CTGF production [23] in $\mathrm{db} /$ $\mathrm{db}$ mice or STZ-induced diabetic nephropathy model. They can also significantly alleviate diabetic organ injury by decreasing the production of $\mathrm{NF}-\mathrm{kB}$ and its downstream synthetases and cytokines [19-25], increasing antioxidant enzyme production [19, 26, 27], and suppressing apoptotic cell death [27, 28].

\section{Antioxidant activity}

Long-term oxidative stress will generate excessive ROS to oxidize protein, lipids, DNA and then cause cell death, tissue damage, and organ dysfunction. Ideal antioxidant drugs are required to regulate the defense system and scavenge excessive ROS. Studies indicated that morroniside (at $1,10,100 \mu \mathrm{mol} \mathrm{L}^{-1}$ ) for $24 \mathrm{~h}$ and total saponins (at 60 and $120 \mathrm{mg} \mathrm{kg}^{-1}$ day $^{-1}$ p.o.) for 4 weeks regulated $\mathrm{Ca}^{2+}$ and $\mathrm{NO}$ release $[29,30]$, the aqueous extract (at $0.25-2.0 \mathrm{mg} \mathrm{mL}^{-1}$ ) for $20 \mathrm{~h} \mathrm{mod-}$ ulated GSH redox cycle [31], the aqueous extract, the ethanol extract (at $0.01-0.1 \mathrm{mg} \mathrm{mL}^{-1}$ ), morroniside (at 0.05-2 $\mu \mathrm{g} \mathrm{mL}^{-1}$ ), and ursolic acid (at $0.05-2 \mu \mathrm{g} \mathrm{mL}^{-1}$ ) for $24 \mathrm{~h}$ promoted antioxidant enzymes syntheses [3133 to inhibit lipid peroxidation [29], 5-hydroxymethylfurfural (at $100-400 \mu \mathrm{mol} \mathrm{L}{ }^{-1}$ ) for 3 days decreased ROS release [34], morroniside (at $100 \mu \mathrm{mol} \mathrm{L}{ }^{-1}$ ) for 2 days recovered cell cycle to normal state [35]. Mentioned effects significantly together reduced the oxidative stress-induced damages compared with the no treatment group. 
<smiles>C=C[C@H]1C2CCOC(=O)C2=CO[C@@H]1O[C@H]1C[C@H](O)[C@@H](O)[C@H](CO)O1</smiles><smiles>COC(=O)CC(OC1C[C@@]2(C)C(C(=O)OC)=CO[C@H](O[C@H]3C[C@H](O)[C@@H](O)C(CO)O3)[C@]2(C)[C@H](C)O1)C(=O)OC</smiles>

13

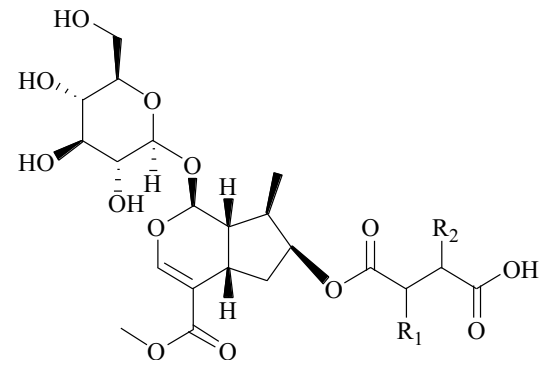

$$
\begin{array}{ccc} 
& \mathrm{R}_{1} & \mathrm{R}_{2} \\
\mathbf{1 4} & \mathrm{OH} & \mathrm{H} \\
\mathbf{1 5} & \mathrm{H} & \mathrm{OH}
\end{array}
$$

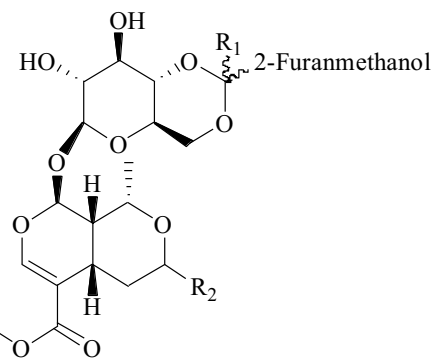

$$
\begin{array}{ccc} 
& \mathrm{R}_{1} & \mathrm{R}_{2} \\
\mathbf{1 6} & \alpha-\mathrm{H} & \alpha-\mathrm{OC}_{2} \mathrm{H}_{5} \\
\mathbf{1 7} & \alpha-\mathrm{H} & \beta-\mathrm{OC}_{2} \mathrm{H}_{5} \\
\mathbf{1 8} & \beta-\mathrm{H} & \beta-\mathrm{OC}_{2} \mathrm{H}_{5} \\
\mathbf{1 9} & \alpha-\mathrm{H} & \beta-\mathrm{OCH}_{3}-2-\text {-Furanmethanol }
\end{array}
$$

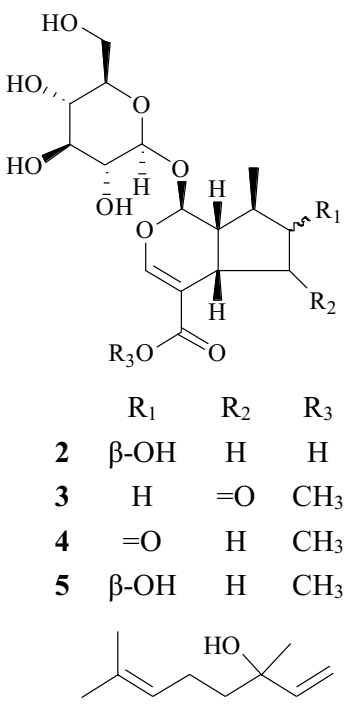

20

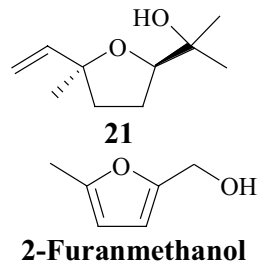

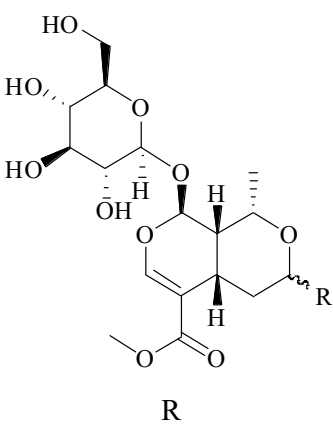

$$
6 \quad \alpha-\mathrm{OH}
$$$$
7 \quad \beta-\mathrm{OH}
$$$$
8 \alpha-\mathrm{OCH} 3
$$$$
9 \quad \beta-\mathrm{OCH}_{3}
$$$$
10 \alpha-\mathrm{OC}_{2} \mathrm{H}_{5}
$$$$
11 \beta-\mathrm{OC}_{2} \mathrm{H}_{5}
$$$$
12 \alpha-\mathrm{OC}_{4} \mathrm{H}_{9}
$$

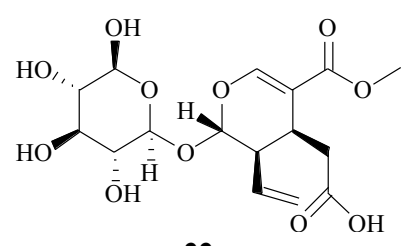

22
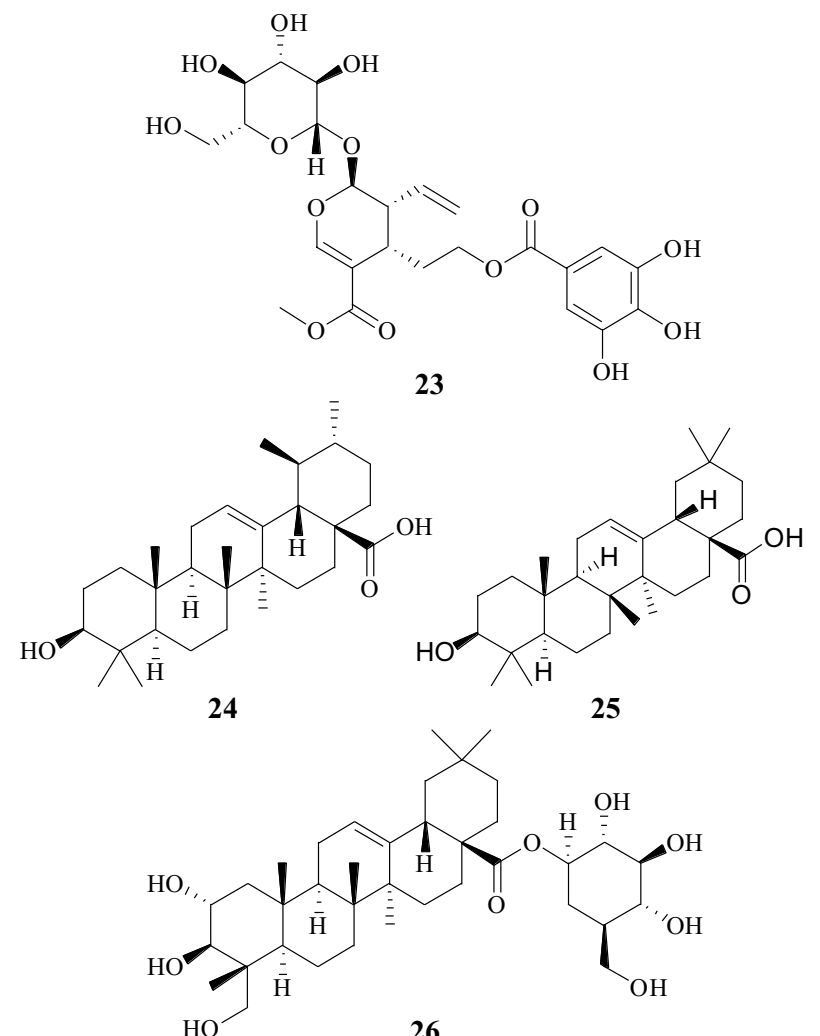

Fig. 2 Structures of chemical constituents from Corni Fructus 


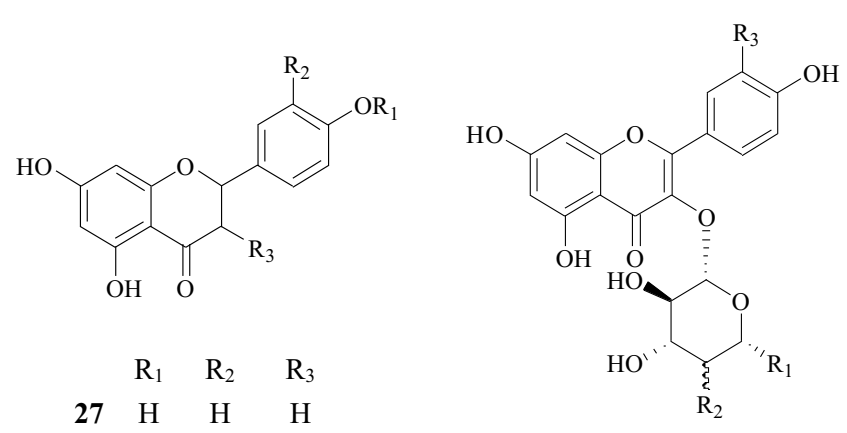

$28 \mathrm{H} \quad \mathrm{H} \quad \mathrm{OH}$

$29 \mathrm{H} \quad \mathrm{CH}_{3} \mathrm{OH}$

$33 \mathrm{H} \quad \mathrm{OH} \quad \mathrm{OH}$<smiles>CCCCOC(=O)C1OC(Oc2c(-c3ccc(O)c(O)c3)oc3cc(O)cc(O)c3c2=O)C(O)C(O)C1O</smiles>

37<smiles>O=C(O)c1cc(O)c(O)c(O)c1</smiles>

40<smiles>O=C(Cl)c1cc(O)c(O)c(O)c1</smiles>

gall<smiles>[R]OC1C(O)OC(CO)C(O)C1O[Ga]</smiles>

R

$44 \mathrm{H}$

45 gall

38<smiles>[R]OC1C(O)OC2COC(=O)c3cc(O)c(O)c(O)c3-c3c(cc(O)c(O)c3O)C(=O)OCC2C1O[Al]</smiles>

$\mathrm{R}$

$42 \mathrm{H}$

49 gall<smiles>C[C@H]1O[C@H](OC[C@H]2O[C@@H](Oc3c(-c4ccc(O)cc4)oc4cc(O)cc(O)c4c3=O)[C@H](O)[C@H](O)[C@H]2O)[C@H](O)[C@@H](O)[C@@H]1O</smiles>

32<smiles>O=c1c(O[C@@H]2OC(CCO)[C@@H](O)[C@H]2O)c(-c2ccc(O)c(O)c2)oc2cc(O)cc(O)c12</smiles>

39<smiles>O=C(OCC[C@@H](O)[C@@H](O)[C@H](O)C(=O)CO)c1cc(O)c(O)c(O)c1</smiles>

41

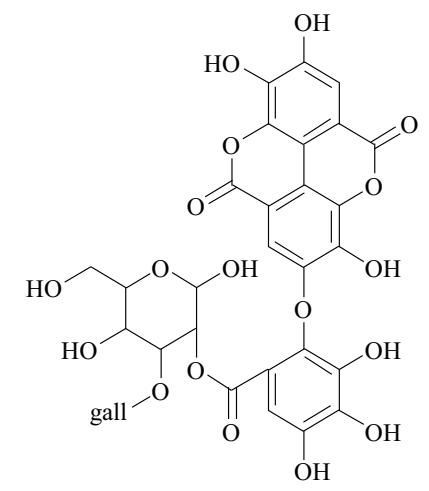

43

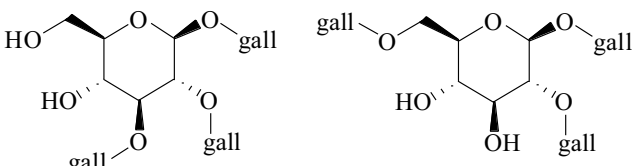

46

47

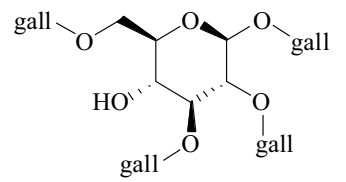

48

Fig. 3 Structures of chemical constituents from Corni Fructus 
<smiles>O=C1OCC2OC(O[Ga])C(O[Si])C(O[Al])C2OC(=O)c2cc(O)c(O)c(O)c2-c2c1cc(O)c(O)c2O</smiles>

50

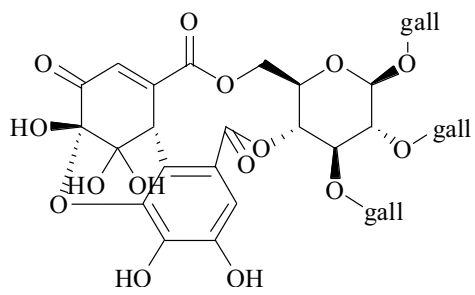

55<smiles>[R2]O[C@H]1C([R])O[C@@H]2COC(=O)c3cc(O)c(O)c(O)c3-c3c(cc(Oc4c(C(=O)O)cc(O)c(O)c4O)c(O)c3O)C(=O)OC1C2O[AlH2]</smiles>

$\begin{array}{ccccc} & \mathrm{R}_{1} & \mathrm{R}_{2} & & \mathrm{R} \\ \mathbf{5 1} & \mathrm{OH} & \mathrm{H} & \mathbf{5 2} & \mathrm{H} \\ \mathbf{5 4} & \text { OH } & \text { gall } & \mathbf{5 3} & \text { gall } \\ \mathbf{5 6} & \text { O-gall } & \text { gall } & & \end{array}$

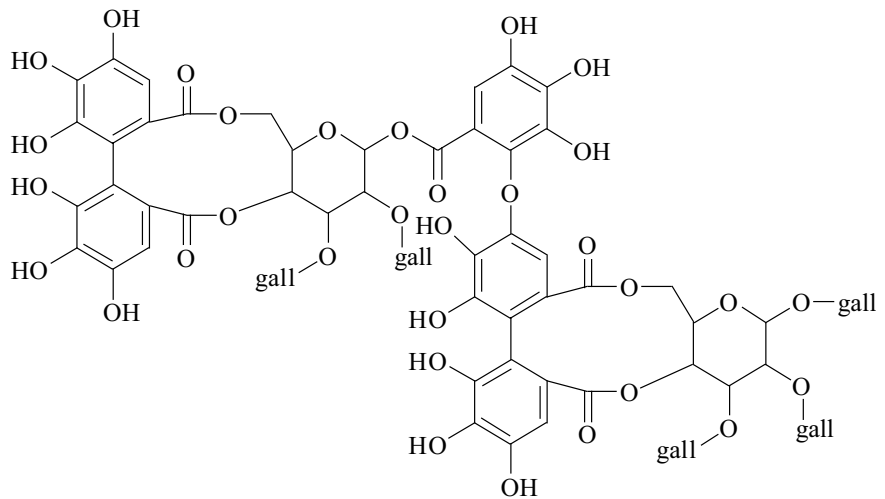

57

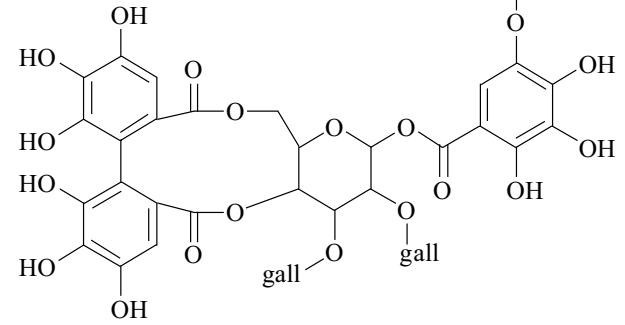<smiles>[R]O[C@H]1[C@@H](O)O[C@@H]2COC(=O)c3cc(Oc4c(C(=O)O)cc(O)c(O)c4O)c(O)c(O)c3-c3c(cc(O)c(O)c3O)C(=O)O[C@H]1[C@@H]2O[Si]</smiles>
all 

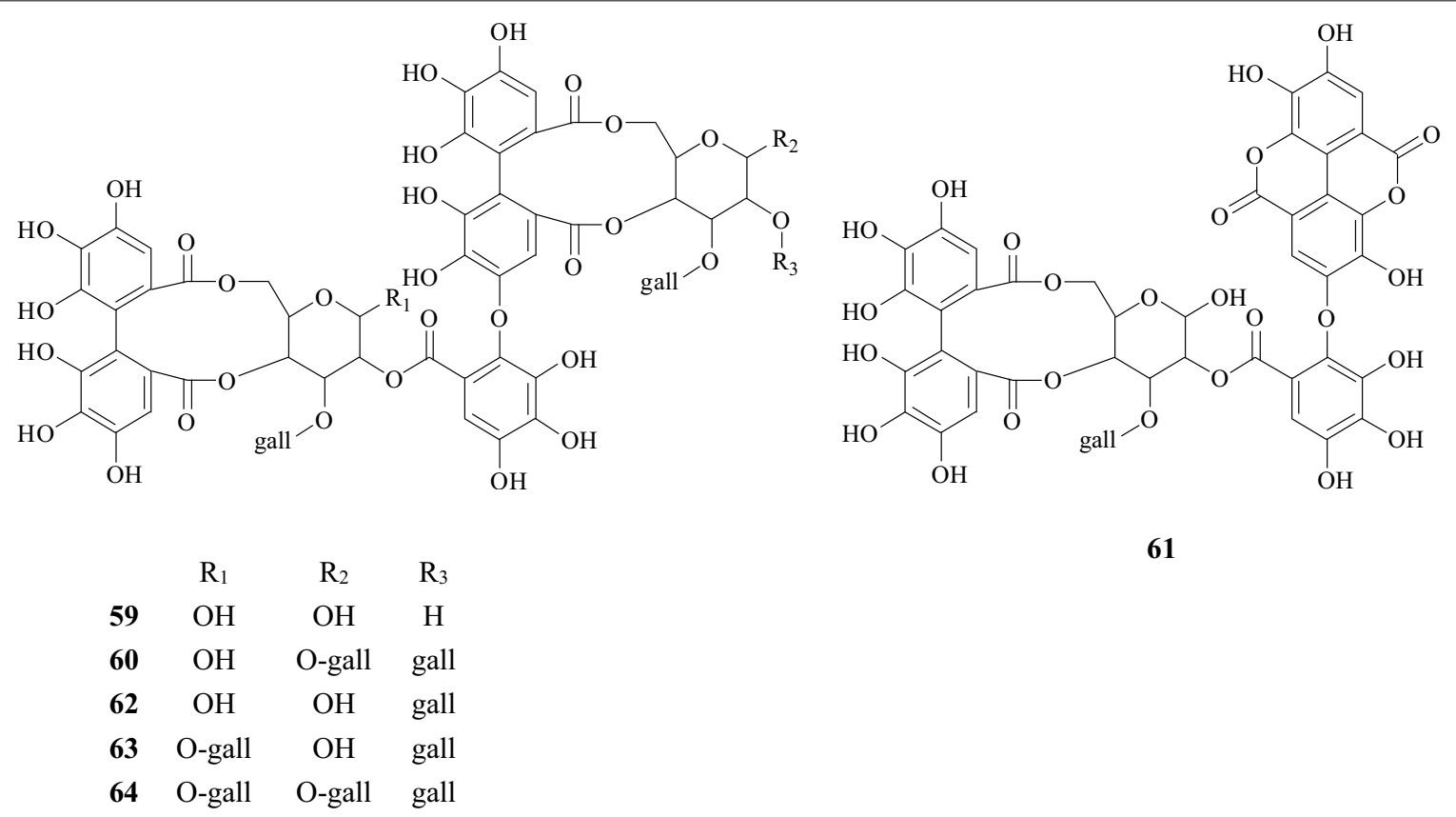

61

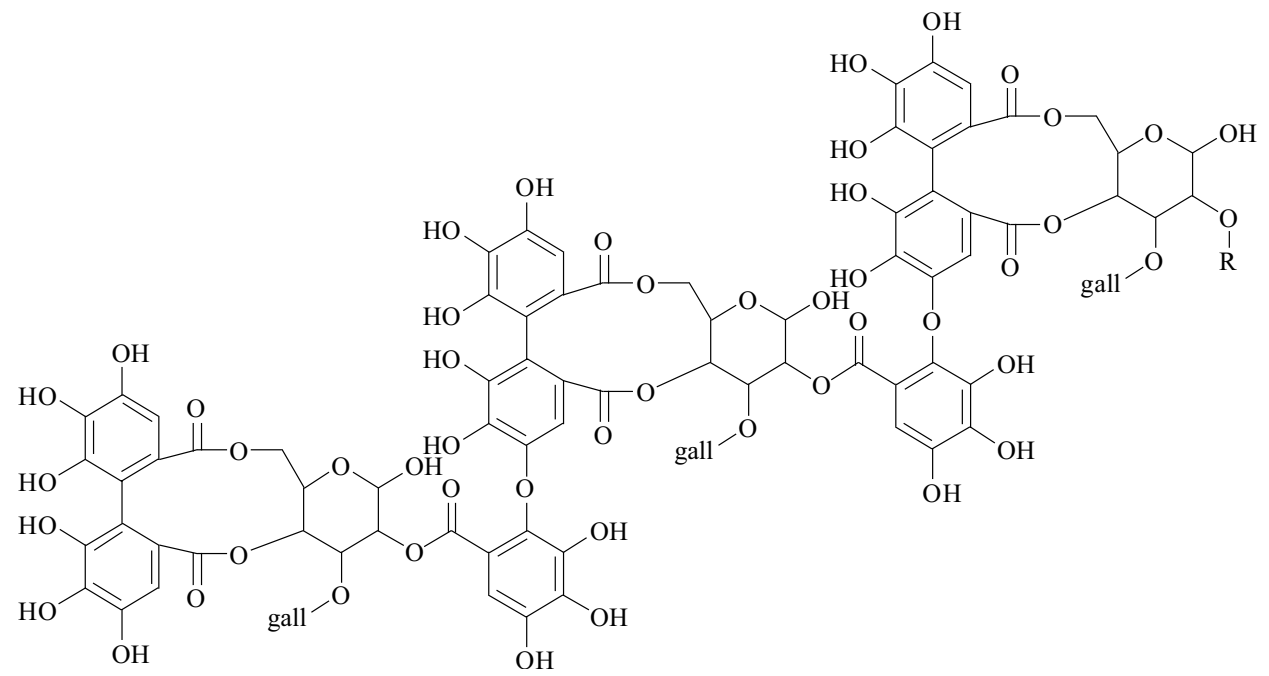

$$
\begin{array}{cc} 
& \mathrm{R} \\
\mathbf{6 5} & \mathrm{H} \\
\mathbf{6 6} & \text { gall }
\end{array}
$$

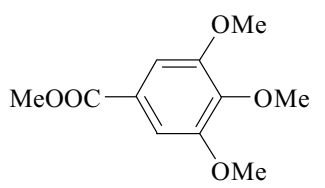

67

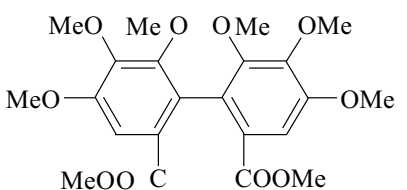

68

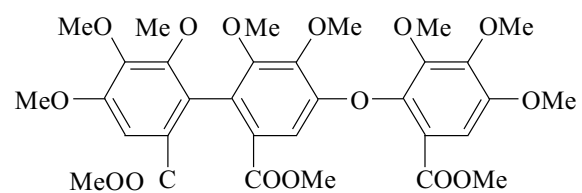

69

Fig. 5 Structures of chemical constituents from Corni Fructus 


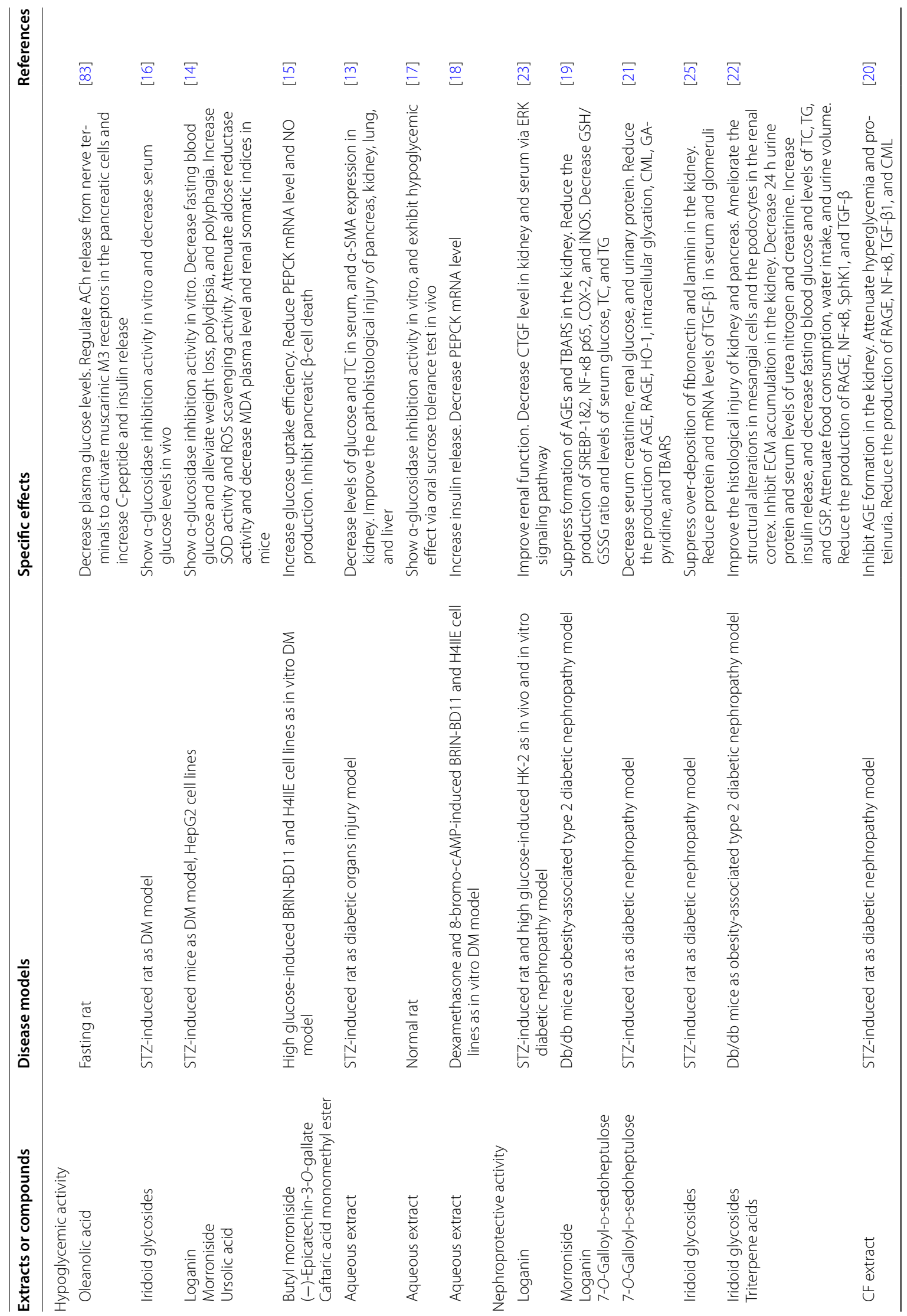




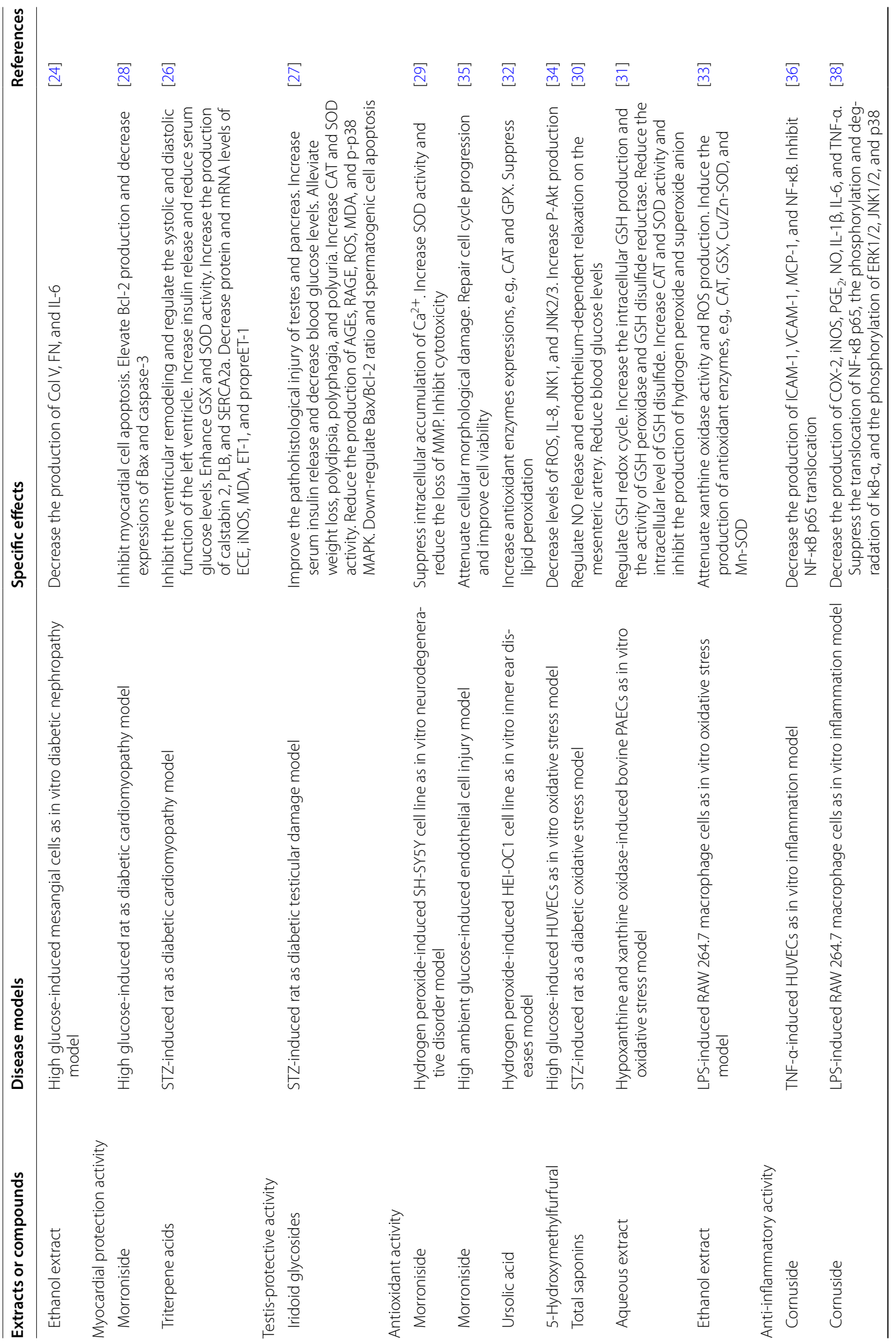




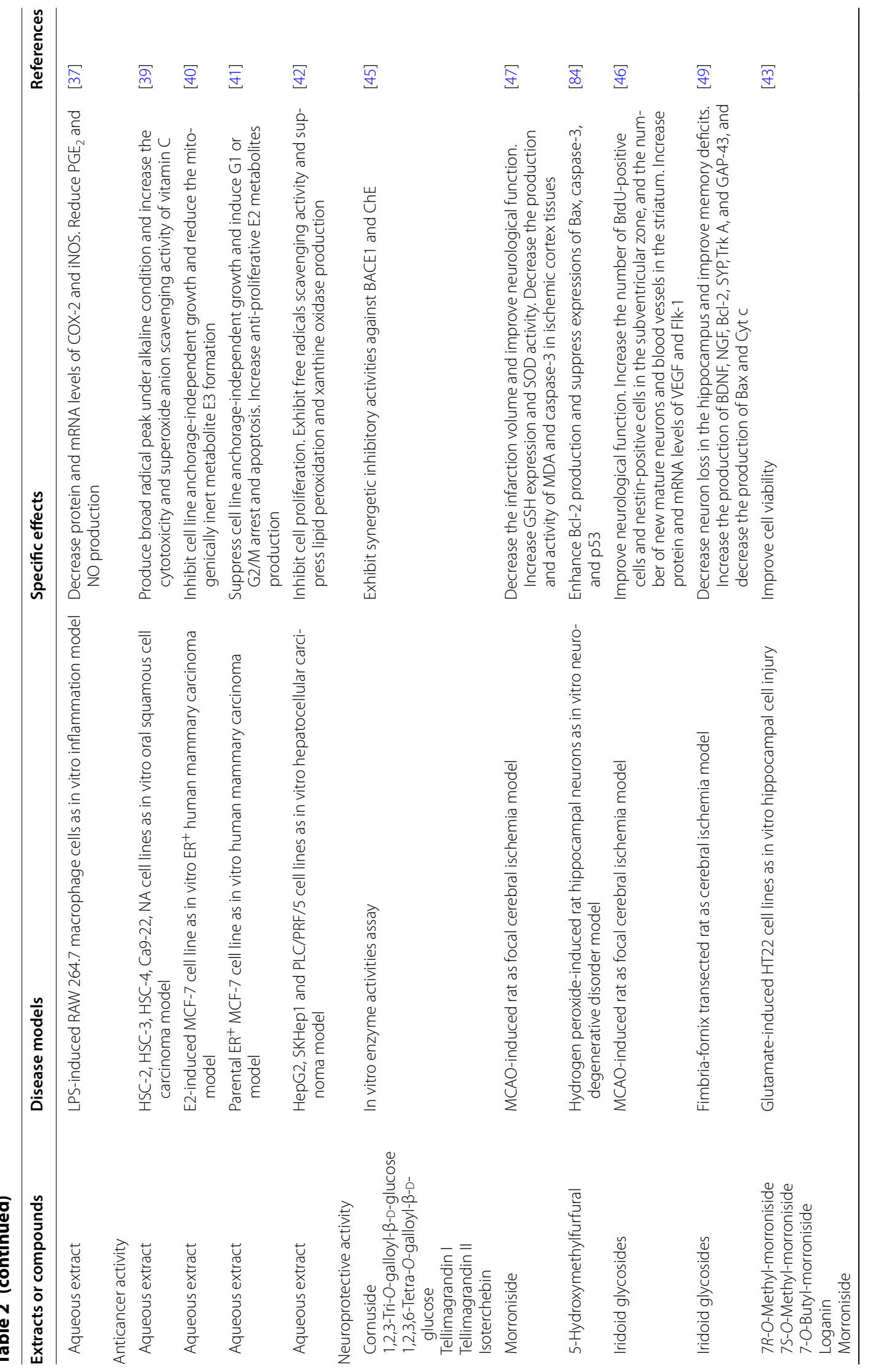



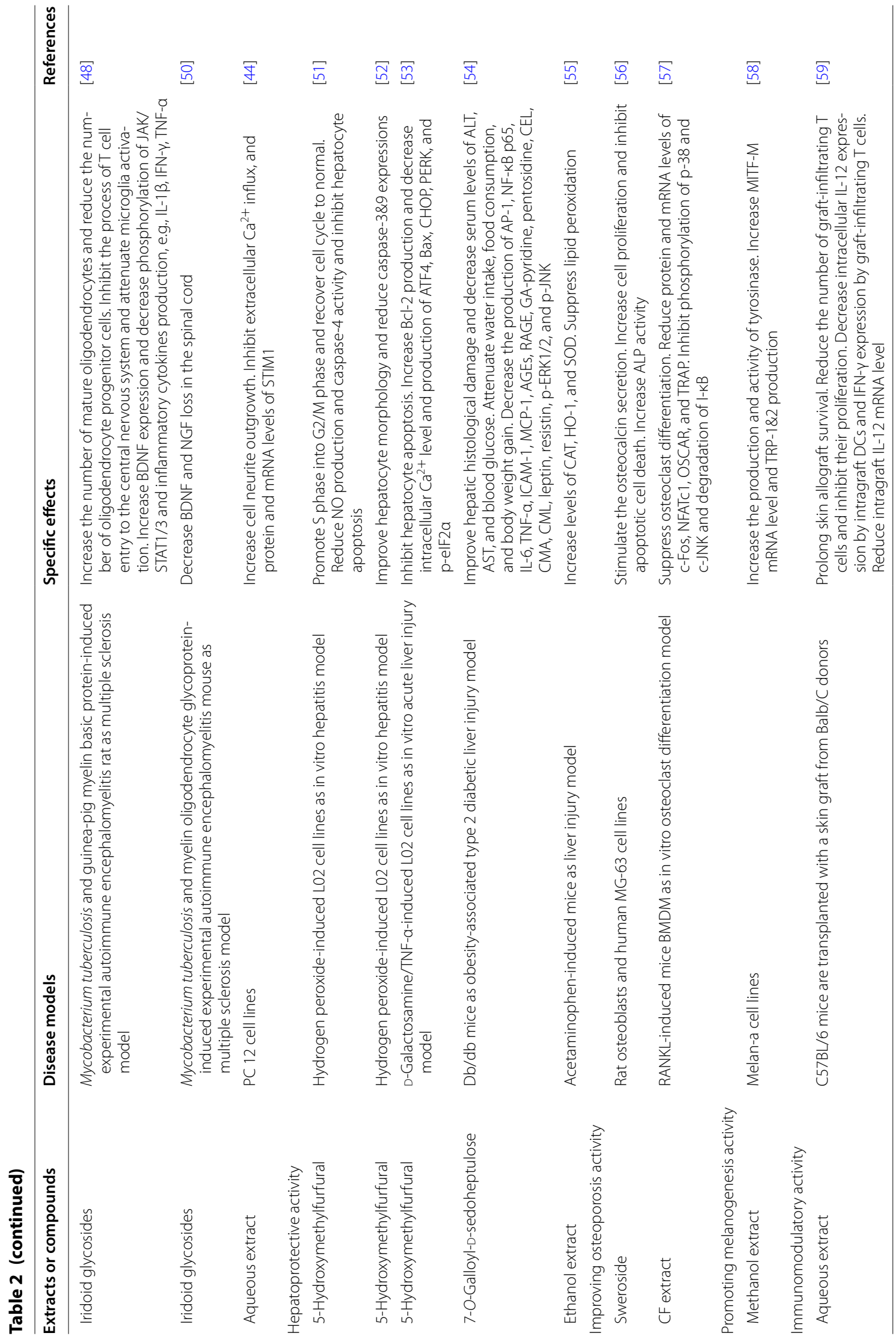


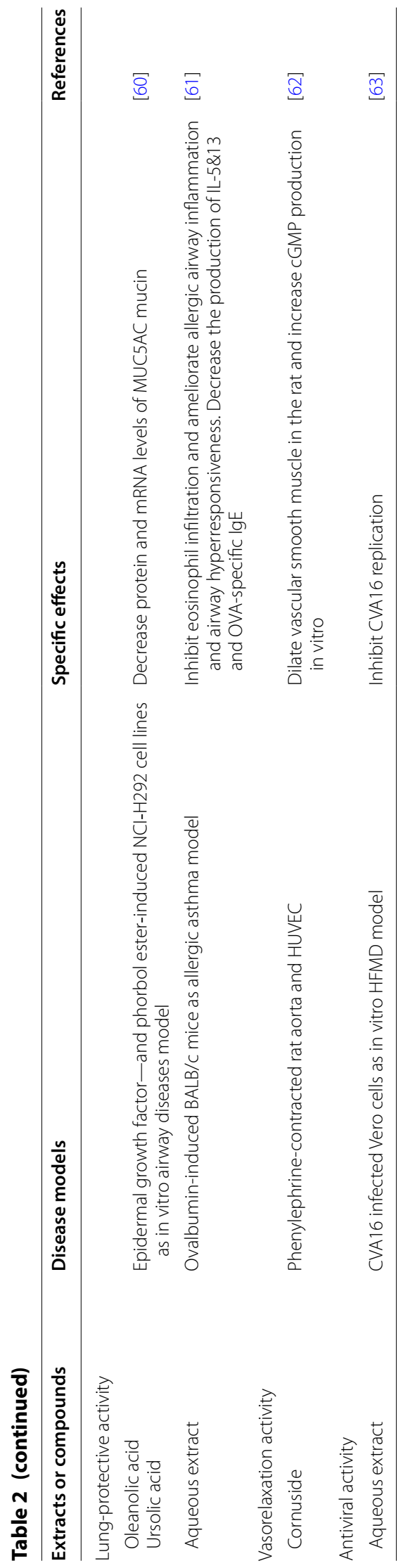




\section{Anti-inflammatory activity}

Prolonged and incurable inflammation may cause many diseases, e.g., atherosclerosis, cancer, ulcerative colitis. In LPS and TNF- $\alpha$-induced cell inflammation models, compared with the no treatment group, $\mathrm{CF}$ aqueous extract (at $0.2,1,5 \mathrm{mg} \mathrm{mL}^{-1}$ ) and cornuside (at 1, 10, $50 \mu \mathrm{mol} \mathrm{L}{ }^{-1}$ ) for $24 \mathrm{~h}$ significantly inhibited NF-kB p65 translocation, down-regulated COX-2 and iNOS production, finally decreased $\mathrm{PGE}_{2}$ and $\mathrm{NO}$ levels to control excessive inflammatory responses [36-38].

\section{Anticancer activity}

CF aqueous extract significantly enhanced both the cytotoxicity and superoxide anion scavenging activity of vitamin $C$ at 0.5 and $36 \mu \mathrm{g} \mathrm{m}^{-1}$, respectively. Together with $\mathrm{CF}$ aqueous extract, vitamin $\mathrm{C}$ further inhibited proliferation and induced apoptosis in several human oral squamous cell carcinoma cell lines. Compared with no treatment, the proliferation inhibition rate was at $1.3-71.0 \%$ [39]. Furthermore, the aqueous extract (at $1.0 \mathrm{mg} \mathrm{mL}^{-1}$ ) for 2 days significantly exhibited anti-ER ${ }^{+}$ human mammary carcinoma activity by inhibiting cell anchorage-independent growth, regulating the metabolism of E2 and E3 [40], and influencing cell cycle progression and cellular apoptosis [41]. Finally, the aqueous extract has been tested for its cancer inhibitory effect in several hepatocellular carcinomas and leukemic cell lines. The study indicated that the aqueous extract inhibited the tumor cell proliferation in a dose-dependent manner at $0.11-0.337 \mathrm{mg} \mathrm{mL} \mathrm{m}^{-1}$, exhibited oxygen free radicals scavenging activity (at $50 \mu \mathrm{g} \mathrm{m}^{-1}$ ), attenuated xanthine oxidase production (at $2.62 \mathrm{mg} \mathrm{mL}^{-1}$ ) and lipid peroxidation (at $0.892 \mathrm{mg} \mathrm{mL}^{-1}$ ) [42]. In this study, CF aqueous extract exhibited the similar effects compared with 5-fluorouracil (at 0.5, 1, $5 \mu \mathrm{g} \mathrm{mL}^{-1}$ ).

\section{Neuroprotective activity}

Many compounds in $\mathrm{CF}$ were further tested for the neuroprotective effects. 7R-O-Methyl-morroniside, 7S-O-methyl-morroniside, 7-O-butyl-morroniside, loganin, and morroniside (each at 10 and $50 \mu \mathrm{mol} \mathrm{L}^{-1}$ ) for $1 \mathrm{~h}$ significantly protected the neurons against glutamate-induced neurotoxicity up to about $78 \%$ compared with the no treatment group [43]. CF aqueous extract (at $60 \mu \mathrm{g} \mathrm{mL}^{-1}$ ) significantly inhibited the extracellular $\mathrm{Ca}^{2+}$ influx to increase cell neurite outgrowth [44]. Also, cornuside, isoterchebin, and tellimagrandin II (each at

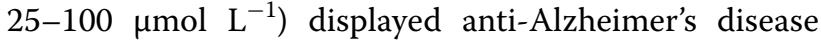
potential due to their synergetic inhibitory activities against BACE1 and ChE [45].

Cerebral ischemia, multiple sclerosis, and neurodegenerative disorder models are applied in animal experiments. Iridoid glycosides (at 60 and $180 \mathrm{mg} \mathrm{kg}^{-1}$ day $^{-1}$ p.o.) for $1-4$ weeks and morroniside (at 90 and $270 \mathrm{mg} \mathrm{kg}^{-1}$ day $^{-1}$ p.o.) for 3 days significantly decreased the infarction volume, increased the number of new mature neurons and blood vessels, and improved nervous system function [46, 47]. Also, iridoid glycosides (at 50-180 $\mathrm{mg} \mathrm{kg}^{-1}$ day $^{-1}$ p.o.) for 3-4 weeks can significantly promote NGF and BDNF production [48-50], and repair the abnormal functions of microglia, oligodendrocyte, and $\mathrm{T}$ cell to maintain the central nervous system homeostasis [48].

\section{Hepatoprotective activity}

In hepatitis cell models, 5-hydroxymethylfurfural (at $0.2-1$ and $0.79 \mu \mathrm{mol} \mathrm{L} \mathrm{L}^{-1}$ ) for $24 \mathrm{~h}$ has been shown to protect hepatocytes from $\mathrm{H}_{2} \mathrm{O}_{2}$ induced-cytotoxicity by significantly decreasing $\mathrm{NO}$ and intracellular $\mathrm{Ca}^{2+}$ levels, inhibiting abnormal production of apoptosis-related proteins and recovering back to regular cell cycle [51-53]. In hepatitis animal models, 7-O-galloyl-D-sedoheptulose (at 20 and $100 \mathrm{mg} \mathrm{kg}^{-1}$ day $^{-1}$ p.o.) for 6 weeks and CF ethanol extract (at $100-500 \mathrm{mg} \mathrm{kg}^{-1}$ day $^{-1}$ p.o.) for 1 week significantly decreased the serum marker enzymes of hepatic damage, weakened the oxidative stress by promoting antioxidant enzymes production and inhibiting lipid peroxidation, finally improved hepatic histological injury $[54,55]$.

\section{Other pharmacological activities}

In addition to the mentioned pharmacological activities, CF has also been reported to exert multiple bioactivities. Firstly, sweroside (at $7.5 \mu \mathrm{g} \mathrm{mL}{ }^{-1}$ ) for 1 week significantly promoted the proliferation and differentiation of osteoblasts via the regulation of osteocalcin [56]. Also, CF extract (at $0-100 \mu \mathrm{g} \mathrm{mL}^{-1}$ ) for 4 days significantly inhibited osteoclast differentiation in a dose-dependent manner via the inhibition of the signaling cascades $\mathrm{NF}-\mathrm{kB} / \mathrm{c}-\mathrm{Fos} / \mathrm{NFATc} 1$ to improve osteoporosis [57]. Secondly, CF methanol extract (at 3.125-12.5 $\mu \mathrm{g} \mathrm{mL}^{-1}$ ) for 3 days significantly up-regulated synthesis and activity of tyrosinase, raised TRP-1\&2 translation associating with increasing transcription of MITF-M, finally promoted melanogenesis by $36.1 \%$ [58]. Thirdly, CF aqueous extract possesses immunomodulatory activity. In C57BL/6 mice that were transplanted with a skin graft from Balb/C donors, CF extract significantly prolonged skin allograft survival synergistically by suppressing Th1 response, promoting regulatory $\mathrm{T}$ cell generation, and enhancing its suppressive function [59]. Fourthly, CF shows lung-protective activity via two studies. In the cellular test, oleanolic acid (at 10 and $100 \mu \mathrm{mol} \mathrm{L}^{-1}$ ) and ursolic acid (at $100 \mu \mathrm{mol} \mathrm{L}^{-1}$ ) for $30 \mathrm{~min}^{\prime}$ pretreatment significantly down-regulated MUC5AC mucin whose excessive 
level would impair airway defenses to cause serious airway diseases [60]. In an animal experiment, CF aqueous extract (at 50 and $200 \mathrm{mg} \mathrm{kg}^{-1} 3$ day $^{-1}$ p.o.) for 5 weeks significantly decreased the production of inflammatory mediators and reduced eosinophil infiltration, finally attenuated allergic airway inflammation and airway hyperresponsiveness [61]. Fifthly, cornuside significantly dilated vascular smooth muscle in phenylephrine-contracted rat aorta via the up-regulation of cGMP level to show its vasorelaxation activity [62]. Finally, among in vitro screening of antiviral drugs for treating hand, foot, and mouth disease (HFMD) infection, CF aqueous extract (at $0.4 \mu \mathrm{g} \mathrm{mL}^{-1}$ ) for 2 days significantly inhibited CVA16 replication in cellular level [63].

\section{Conclusion}

$\mathrm{CF}$ is recognized as a fundamental constituent part of tonifying Yin and Yang prescription because of its harmonious and complementary features according to the basic theory of TCM. It possesses the properties of sour and astringent. Firstly, sour and sweet herbs can be combined to nourish Yin, it can act as the sovereign and ministerial drug among Radix Rehmanniae Praeparata, Dioscoreae Rhizoma, Lycii Fructus, Ligustri Lucidi Fructus, Schisandrae Chinensis Fructus. Also, sour and astringent properties exhibit their function of astringing and storing. It also behaves as the sovereign and the ministerial drug that combines with Euryales Semen, Sepiae Endoconcha, Mantidis Oötheca, Rubi Fructus, Paeoniae Radix Alba to treat spermatorrhea, urorrhagia, metrorrhagia and metrostaxis, and excessive perspiration. Finally, CF can be as the adjuvant and conductant drug to alleviate warm and dry features of Yang-reinforcing drugs.

Chemical constituents from terpenoids, flavonoids, tannins, and furans exhibited diverse biological activities, including hypoglycemic, neuroprotective, heart-protective, hepatoprotective, nephroprotective, testis-protective activities. Pharmacological activities are outlined in Fig. 6. In these studies, bioactive components from $\mathrm{CF}$ mainly alleviated the damage of target organs by antioxidant activity, anti-inflammatory activity, and antiapoptosis activity, i.e., up-regulating the expressions and activities of antioxidant enzymes, down-regulating the levels of cytokines and chemokines, and modulating the abnormal expressions of apoptotic death associated proteins.

Hypoglycemic activity and alleviating diabetic target organs damage are critical pharmacological activities among the broad spectrum of pharmacological activities of CF. Morroniside, loganin, oleanolic acid, ursolic acid, and 7-O-galloyl-D-sedoheptulose exhibited the similar efficacy compared with the conventional oral hypoglycemic drugs (acarbose and metformin). In vivo studies, they reduced serum glucose levels and alleviated unusual symptoms caused by diabetes. In cellular assays, they protected pancreatic $\beta$ cell from oxidative damage, increased insulin release, improved insulin resistance, displayed $\alpha$-glucosidase inhibition activity, and

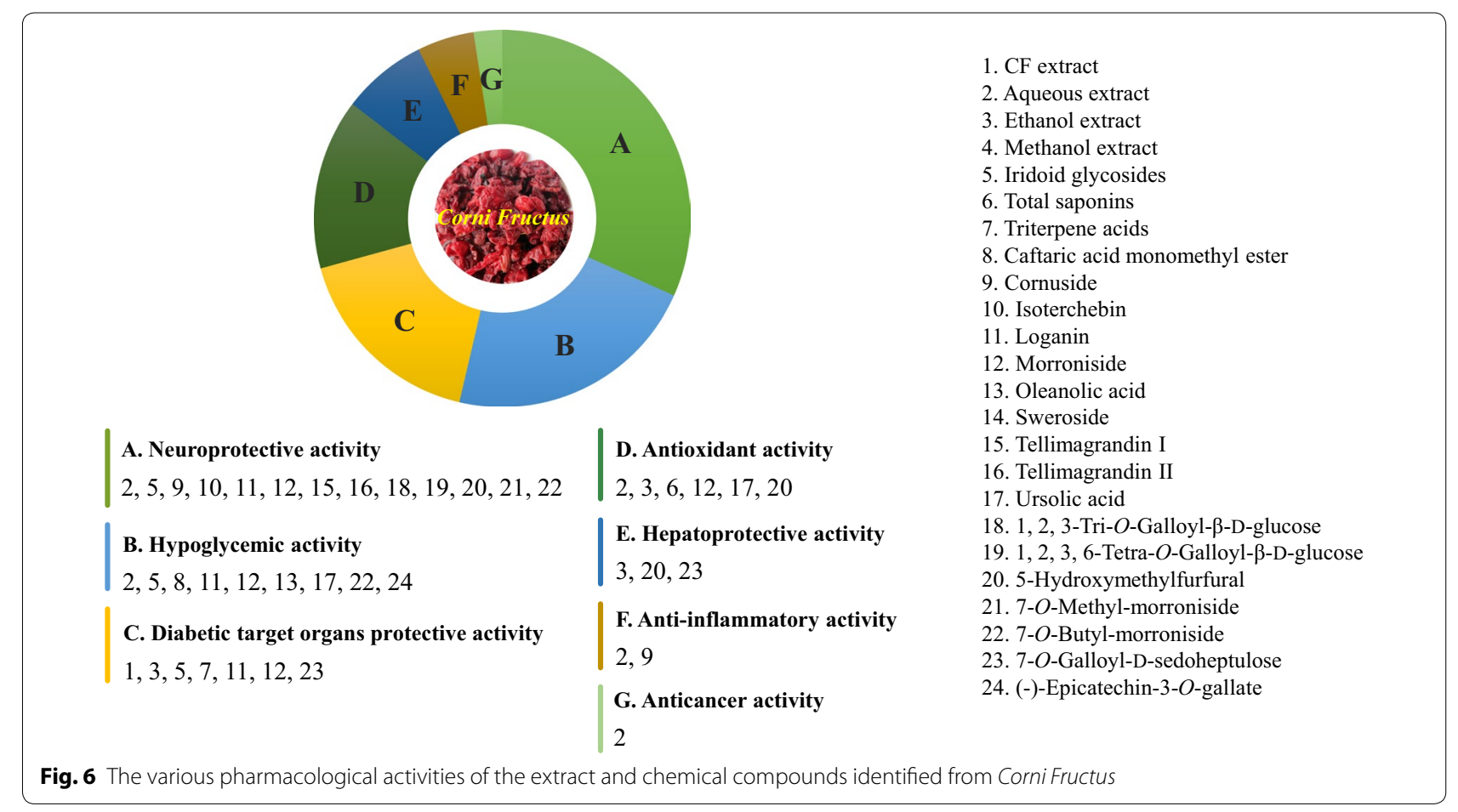


suppressed liver gluconeogenesis. Also, compounds alleviated the high-glucose triggered target organs damage by attenuating oxidative stress, inflammation, and apoptosis, finally kept the essential function of target organs stable. CF has also been widely used to treat DM in clinical work. For example, Jingui Shenqi Wan and Liuwei Dihuang Wan are two classic Chinese medicinal formulae which contain CF. Clinical trials indicated that Jingui Shenqi Wan and Liuwei Dihuang Wan could decrease serum glucose levels, alleviate typical DM symptoms and repair target organs injury [64-67]. Diverse anti-diabetes and anti-diabetic complication pharmacological activities make $\mathrm{CF}$ a potential herb to become the complementary drug for treating DM.

Another significant biological activity is the neuroprotection. In cerebral ischemia rat model and neurodegenerative disorder cellular model, iridoid glycosides (e.g., morroniside) and 5-hydroxymethylfurfural increased the number of new mature neurons and blood vessels and exerted anti-oxidative stress, anti-inflammation, and anti-apoptosis properties. In cerebral ischemia rat model and multiple sclerosis rats and mice models, iridoid glycosides also enhanced the levels of brain-derived neurotrophic factor and nerve growth factor. Current studies showed that the pathogenic mechanisms of neurodegenerative diseases have the close relationship with autophagy deficiency and abnormal proteins aggregate clearance dysfunction [68, 69]. In addition to the antiapoptotic activity, pharmacological activities of CF on the regulation of autophagy can be further explored. Furthermore, many classic Chinese medicinal formulae have been used to treat neurological disorders belonging to liver and kidney deficiency [70-72]. For example, Liuwei Dihuang Wan treats insomnia, Zuogui Wan (左 归丸) treats epilepsy and vertigo, Dabu Yinjian (大补阴 煎) treats a headache, Zuogui Wan and Dihuang Yinzi (地 黄饮子) treats stroke, and Huanshao Dan (还少丹) treats dementia. CF plays a vital role in nourishing liver and kidney Yin in these Chinese medicinal formulae.

However, about 90 compounds have been isolated and identified from CF, only $18 \%$ compounds are further assayed for their pharmacological activities in vivo and in vitro. It indicates that pharmacological activities of the remaining $90 \%$ chemical components are still unknown yet. Moreover, current studies do not provide enough evidence to verify the drug binding sites of active ingredients of CF. For example, it is difficult to judge whether these active ingredients bind the $G$ protein coupled receptor, ion channels, transmembrane receptor kinases, or nuclear receptors to work. Therefore, more systematic and detailed pharmacological studies on CF need to be fulfilled in the future.

\section{Abbreviations}

ACh: acetyl choline; AGEs: advances glycation endproducts; ALP: alkaline phosphatase; ALT: alanine aminotransferase; AST: aspartate aminotransferase; ATF4: activating transcription factor 4; BACE1: b-site amyloid precursor protein cleaving enzyme 1; Bax: bcl-2-associated X; Bcl-2: B-cell lymphoma-2; BDNF: brain-derived neurotrophic factor; BMDM: bone marrow-derived macrophages; BrdU: bromodeoxyuridine; CAT: catalase; CEL: Ne-(carboxyethyl) lysine; ChE: cholinesterase; CHOP: C/EBP homologous protein; CMA: Ne(carboxymethyl)arginine; CML: Ne-(carboxymethyl)lysine; Col V: collagen V; COX-2: cyclooxygenase-2; CTGF: connective tissue growth factor; CVA16: Coxsackie virus A group 16 strain; Cyt c: cytochrome C; DCs: dendritic cells; E2: 17ß-estradiol; E3: estrone; ECE: endothelin converting enzyme; ECM: extracellular matrix; $\mathrm{ER}^{+}$: estrogen receptor-positive; ERK1/2: extracellularsignal-related kinase 1/2; ET-1: endothelin-1; FN: fibronectin; GAP-43: growthassociated protein-43; GC-MS: gas chromatography-mass spectrometry; GPX: glutathione peroxidase; GSH: glutathione; GSP: glycated serum protein; GSSG: glutathione disulfide; HK-2: human renal proximal tubular epithelial cells; HO-1: heme oxygenase-1; HUVECs: human umbilical vein endothelial cells; ICAM-1: intercellular adhesion molecule-1; iNOS: inducible nitric oxide synthase; IFN: interferon; IL: interleukin; JNK: c-Jun N-terminal kinase; LPS: lipopolysaccharide; MAPK: mitogen-activated protein kinase; MCAO: middle cerebral artery occlusion; MCP-1: monocyte chemoattractant protein 1; MDA: malondialdehyde; MITF-M: microphthalmia-associated transcription factor-M; MMP: mitochondrial membrane potential; NF-kB: nuclear factorkappa B; NFATC1: nuclear factor of activated T cells cytoplasmic 1; NGF: nerve growth factor; NO: nitric oxide; OSCAR: osteoclast-associated receptor; OVA: ovalbumin; $p$-elF2a: $p$-eukaryotic initiation factor 2 alpha; PAECs: pulmonary artery endothelial cells; PEPCK: phosphoenolpyruvate carboxykinase; PERK: protein kinase $R$ (PKR)-like endoplasmic reticulum kinase; $\mathrm{PGE}_{2}$ : prostaglandin $E_{2}$; PLB: phospholamban; p.o.: per os; RAGE: receptor of AGE; RANKL: receptor activator of nuclear factor kappa-B ligand; ROS: reactive oxygen species; SERCA2a: sarcoplasmic reticulum $\mathrm{Ca}^{2+}$-ATPase 2a; SOD: superoxide dismutase; SPHK1: sphingosine kinase 1; SREBP-1\&2: sterol regulatory element binding protein-1\&2; STIM1: sensor protein stromal interaction molecule 1; STZ: streptozotocin; SYP: synaptophysin; TBARS: thiobarbituric acid-reactive substance; TC: triglyceride; TG: total cholesterol; TGF: transforming growth factor; TNF-a: tumor necrosis factor-a; TRAP: tartrate-resistant acid phosphatase; Trk A: tyrosine receptor kinase A; TRP-1\&2: tyrosinase-related protein-1\&2; VCAM-1: vascular cell adhesion molecule-1; VEGF: vascular endothelial growth factor.

\section{Authors' contributions}

YD conducted literature searches, extracted and analyzed data and drafted the manuscript and prepared tables and figures. ZLF contributed to the proofreading of chemical constituents and structures. FSW contributed to the draft of the fundamental theories of traditional Chinese medicine of the review. HBC contributed to the revisions of the manuscript. JHL designed the study, developed and revised the manuscript and is the corresponding author All authors read and approved the final manuscript.

\section{Author details}

${ }^{1}$ State Key Laboratory of Quality Research in Chinese Medicine, Institute of Chinese Medical Sciences, University of Macau, Room 7015, N22, Avenida da Universidade, Taipa, Macau SAR, People's Republic of China. ${ }^{2}$ School of Chinese Medicine, Hong Kong Baptist University, Hong Kong, SAR, People's Republic of China. ${ }^{3}$ Ulcerous Vascular Surgical Department, Beijing Traditional Chinese Medicine Hospital Affiliated to Capital Medical University, Beijing, People's Republic of China.

\section{Acknowledgements}

Not applicable.

Competing interests

The authors declare that they have no competing interests.

Availability of data and materials

All data used in this systematic review are fully available in the public domain.

Consent for publication

Not applicable. 
Ethics approval and consent to participate

Not applicable.

\section{Funding}

This work was supported by Macau government Grants FDCT-022/2015/A1 and FDCT-092-2015-A3, the University of Macau Grants MYRG2016-0019-ICMS -QRCM and MYRG2017-00147-ICMS awarded to Jia-Hong Lu.

\section{Publisher's Note}

Springer Nature remains neutral with regard to jurisdictional claims in published maps and institutional affiliations.

Received: 29 April 2018 Accepted: 15 June 2018

Published online: 25 June 2018

\section{References}

1. Chinese Pharmacopoeia Commission. People's Republic of China pharmacopoeia 2015 edition, 1st part. Beijing: China Medical Science Press; 2015. p. 27-8 (in Chinese).

2. Xiang CK. Research progress on resources and active components of Cornus officinalis. Hebei Med J. 2016;38:1886-9 (in Chinese).

3. Song $X Y$, Chen Q, Qi XY. Effect of Liuwei Dihuang pill on erythrocyte aldose reductase activity in early diabetic nephropathy patients. Chin J Integr Tradit West Med. 2004;24:1087-90.

4. Liu XD, Fu J, Feng MZ, Zhang ZH. Effect of Jinggui Shenqi pill combined with nifedipine for the treatment of elderly hypertensive patients with spleen-kidney Yang deficiency syndrome. China J Chin Mater Med. 2015:40:4908-12 (in Chinese).

5. Wang Y, Wang C. Three cases of clinical application of Guchong Decoction. China J Tradit Chin Med Pharm. 2010;25:2041-3 (in Chinese).

6. Hatano T, Ogawa N, Kira R, Yasuhara T, Okuda T. Tannins of cornaceous plants. I. Cornusiins A, B and C, dimeric monomeric and trimeric hydrolyzable tannins from Cornus officinalis, and orientation of valoneoyl group in related tannins. Chem Pharm Bull. 1989;37:2083-90.

7. Hatano T, Ogawa N, Kira R, Yasuhara T, Okuda T. Tannins of cornaceous plants. II. Cornusiins D, E and F, new dimeric and trimeric hydrolyzable Tannins from Cornus officinalis. Chem Pharm Bull. 1989;37:2665-9.

8. Wu Y, Wang $X$, Shen B, Kang L, Fan E. Extraction, structure, and bioactivities of the polysaccharides from Fructus corni. Recent Pat Food Nutr Agric. 2013:5:57-61

9. Yin X, You Q, Jiang Z, Zhou X. Optimization for ultrasonic-microwave synergistic extraction of polysaccharides from Cornus officinalis and characterization of polysaccharides. Int J Biol Macromol. 2016;83:226-32.

10. Chen $\mathrm{H}$, Zhang $\mathrm{HJ}$, Zhang MJ, Xiao ZH. Orthogonal test for optimization of extraction condition for volatile components of Cornus officinalis and extract analysis by GC-MS. J Third Mil Med Univ. 2007;29:1079-82 (in Chinese)

11. Li GY, Yao YX, Ding X. Studies on chemistry component and the biological activity of petroleum ether extraction from pre- and post-processed of Cornus officinalis. Zhong Yao Cai. 2010;33:192-5 (in Chinese)

12. Wen YY, Ren Q, Zhang GM, Li AN, Ding ZE. Analysis of the essential oils from Cornus officinalis by simultaneous distillation extraction coupled with gas chromatography-mass spectrometry. Food Ferment Ind. 2010;36:166-70

13. Han Y, Jung HW, Park YK. Selective therapeutic effect of Cornus officinalis fruits on the damage of different organs in STZ-induced diabetic rats. Am J Chin Med. 2014;42:1169-82.

14. He K, Song S, Zou Z, Feng M, Wang D, Wang Y, Li X, Ye X. The hypoglycemic and synergistic effect of loganin, morroniside, and ursolic acid isolated from the fruits of Cornus officinalis. Phytother Res. 2015;30:283-91.

15. Lin MH, Liu HK, Huang WJ, Huang CC, Wu TH, Hsu FL. Evaluation of the potential hypoglycemic and beta-cell protective constituents isolated from Corni Fructus to tackle insulin-dependent diabetes mellitus. J Agric Food Chem. 2011;59:7743-51.

16. He LH. Comparative study on alpha-glucosidase inhibitory effects of total iridoid glycosides in the crude products and the wine-processed products from Cornus officinalis. Yakugaku Zasshi. 2011;131:1801-5.
17. Park CH, Noh JS, Tanaka T, Uebaba K, Cho EJ, Yokozawa T. The effects of Corni Fructus extract and its fractions against a-glucosidase inhibitory activities in vitro and sucrose tolerance in normal rats. Am J Chin Med. 2011;39:367-80.

18. Chen CC, Hsu CY, Chen CY, Liu HK. Fructus Corni suppresses hepatic gluconeogenesis related gene transcription, enhances glucose responsiveness of pancreatic beta-cells, and prevents toxin induced beta-cell death. J Ethnopharmacol. 2008;117:483-90.

19. Yokozawa T, Kang KS, Park CH, Noh JS, Yamabe N, Shibahara N, Tanaka T. Bioactive constituents of Corni Fructus: the therapeutic use of morroniside, loganin, and 7-O-galloyl-D-sedoheptulose as renoprotective agents in type 2 diabetes. Drug Discov Ther. 2010;4:223-34.

20. Yamabe N, Kang KS, Goto E, Tanaka T, Yokozawa T. Beneficial effect of Corni Fructus, a constituent of Hachimi-jio-gan, on advanced glycation end-product-mediated renal injury in streptozotocin-treated diabetic rats. Biol Pharm Bull. 2007;30:520-6.

21. Yamabe N, Kang KS, Park CH, Tanaka T, Yokozawa T. 7-O-galloyl-D-sedoheptulose is a novel therapeutic agent against oxidative stress and advanced glycation endproducts in the diabetic kidney. Biol Pharm Bull. 2009:32:657-64.

22. Lv X, Dai G, Lv G, Chen Y, Wu Y, Shen H, Xu H. Synergistic interaction of effective parts in Rehmanniae Radix and Cornus officinalis ameliorates renal injury in C57BL/KsJ-db/db diabetic mice: involvement of suppression of AGEs/RAGE/SphK1 signaling pathway. J Ethnopharmacol. 2016;185:110-9.

23. Jiang WL, Zhang SP, Hou J, Zhu HB. Effect of loganin on experimental diabetic nephropathy. Phytomedicine. 2012;19:217-22.

24. Ma W, Wang KJ, Cheng CS, Yan GQ, Lu WL, Ge JF, Cheng YX, Li N. Bioactive compounds from Cornus officinalis fruits and their effects on diabetic nephropathy. J Ethnopharmacol. 2014;153:840-5.

25. Xu HQ, Hao HP. Effects of iridoid total glycoside from Cornus officinalis on prevention of glomerular overexpression of transforming growth factor beta 1 and matrixes in an experimental diabetes model. Biol Pharm Bull. 2004;27:1014-8.

26. Qi MY, Liu HR, Dai DZ, Li N, Dai Y. Total triterpene acids, active ingredients from Fructus Corni, attenuate diabetic cardiomyopathy by normalizing ET pathway and expression of FKBP12.6 and SERCA2a in streptozotocin-rats. J Pharm Pharmacol. 2008;60:1687-94.

27. Chen Y, Wu Y, Gan X, Liu K, Lv X, Shen H, Dai G, Xu H. Iridoid glycoside from Cornus officinalis ameliorated diabetes mellitus-induced testicular damage in male rats: involvement of suppression of the AGEs/RAGE/p38 MAPK signaling pathway. J Ethnopharmacol. 2016;194:850-60.

28. Pi WX, Feng XP, Ye LH, Cai BC. Combination of morroniside and diosgenin prevents high glucose-induced cardiomyocytes apoptosis. Molecules. 2017;22:163.

29. Wang W, Sun F, An Y, Ai H, Zhang L, Huang W, Li L. Morroniside protects human neuroblastoma SH-SY5Y cells against hydrogen peroxideinduced cytotoxicity. Eur J Pharmacol. 2009;613:19-23.

30. Liu Y, Liu H, Zhang J. Total saponins of Cornus officinalis Sieb. ameliorates the endothelium dependent relaxation of mesenteric artery by regulating nitric oxide release in streptozotocin-induced diabetic rats. Zhong Nan Da Xue Xue Bao Yi Xue Ban. 2012;37:757-64.

31. Peng Q, Wei Z, Lau BH. Fructus corni enhances endothelial cell antioxidant defenses. Gen Pharmacol. 1998;31:221-5.

32. Yu HH, Hur JM, Seo SJ, Moon HD, Kim HJ, Park RK, You YO. Protective effect of ursolic acid from Cornus officinalis on the hydrogen peroxide-induced damage of HEl-OC1 auditory cells. Am J Chin Med. 2009;37:735-46.

33. Hwang KA, Hwang YJ, Song J. Antioxidant activities and oxidative stress inhibitory effects of ethanol extracts from Cornus officinalis on raw 264.7 cells. BMC Complement Altern Med. 2016;16:196.

34. Cao G, Cai H, Cai B, Tu S. Effect of 5-hydroxymethylfurfural derived from processed Cornus officinalis on the prevention of high glucose-induced oxidative stress in human umbilical vein endothelial cells and its mechanism. Food Chem. 2013;140:273-9.

35. Xu HQ, Hao HP, Zhang X, Pan Y. Morroniside protects cultured human umbilical vein endothelial cells from damage by high ambient glucose. Acta Pharmacol Sin. 2004;25:412-5.

36. Kang DG, Moon MK, Lee AS, Kwon TO, Kim JS, Lee HS. Cornuside suppresses cytokine-induced proinflammatory and adhesion molecules in the human umbilical vein endothelial cells. Biol Pharm Bull. 2007:30:1796-9. 
37. Chu Q, Hashimoto K, Satoh K, Wang Q, Sakagami H. Effect of three herbal extracts on NO and PGE2 production by activated mouse macrophagelike cells. In Vivo. 2009;544:537-44.

38. Choi YH, Jin GY, Li GZ, Yan GH. Cornuside suppresses lipopolysaccharideinduced inflammatory mediators by inhibiting nuclear factor-kappa B activation in RAW 264.7 macrophages. Biol Pharm Bull. 2011;34:959-66.

39. Chu Q, Satoh K, Kanamoto T, Terakubo S, Nakashima H, Wang Q, Sakagami $H$. Antitumor potential of three herbal extracts against human oral squamous cell lines. Anticancer Res. 2009;29:3211-9.

40. Telang NT, Li G, Sepkovic DW, Bradlow HL, Wong GY. Anti-proliferative effects of Chinese herb Cornus officinalis in a cell culture model for estrogen receptor-positive clinical breast cancer. Mol Med Rep. 2012;5:22-8.

41. Telang N, Li G, Katdare M, Sepkovic D, Bradlow L, Wong G. Inhibitory effects of Chinese nutritional herbs in isogenic breast carcinoma cells with modulated estrogen receptor function. Oncol Lett. 2016;12:3949-57.

42. Chang JS, Chiang LC, Hsu FF, Lin CC. Chemoprevention against hepatocellular carcinoma of Cornus officinalis in vitro. Am J Chin Med. 2004:32:717-25.

43. Jeong EJ, Kim TB, Yang H, Kang SY, Kim SY, Sung SH, Kim YC. Neuroprotective iridoid glycosides from Cornus officinalis fruits against glutamate-induced toxicity in HT22 hippocampal cells. Phytomedicine. 2012;19:317-21.

44. Wang X, Liu J, Jin N, Xu D, Wang J, Han Y, Yin N. Fructus corni extractinduced neuritogenesis in PC12 cells is associated with the suppression of stromal interaction molecule 1 expression and inhibition of $\mathrm{Ca}^{2+}$ influx. Exp Ther Med. 2015;9:1773-9.

45. Bhakta HK, Park CH, Yokozawa T, Tanaka T, Jung HA, Choi JS. Potential anticholinesterase and $\beta$-site amyloid precursor protein cleaving enzyme 1 inhibitory activities of cornuside and gallotannins from Cornus officinalis fruits. Arch Pharm Res. 2017:40:836-53.

46. Yao RQ, Zhang L, Wang W, Li L. Cornel iridoid glycoside promotes neurogenesis and angiogenesis and improves neurological function after focal cerebral ischemia in rats. Brain Res Bull. 2009;79:69-76.

47. Wang W, Xu J, Li L, Wang P, Ji X, Ai H, Zhang L, Li L. Neuroprotective effect of morroniside on focal cerebral ischemia in rats. Brain Res Bull. 2010;83:196-201.

48. Yin L, Chen Y, Qu Z, Zhang L, Wang Q, Zhang Q, Li L. Involvement of JAK STAT signaling in the effect of cornel iridoid glycoside on experimental autoimmune encephalomyelitis amelioration in rats. J Neuroimmunol. 2014:274:28-37.

49. Zhao L, Ding Y, Zhang L, Li L. Cornel iridoid glycoside improves memory ability and promotes neuronal survival in fimbria-fornix transected rats. Eur J Pharmacol. 2010;647:68-74.

50. Qu Z, Zheng N, Zhang Y, Zhang L, Liu J, Wang Q, Yin L. Preventing the BDNF and NGF loss involved in the effects of cornel iridoid glycoside on attenuation of experimental autoimmune encephalomyelitis in mice. Neurol Res. 2016;38:831-7.

51. Ding $X$, Wang MY, Yao $Y X$, Li GY, Cai BC. Protective effect of 5-hydroxymethylfurfural derived from processed Fructus Corni on human hepatocyte L02 injured by hydrogen peroxide and its mechanism. J Ethnopharmacol. 2010:128:373-6.

52. Wang MY, Zhao FM, Peng HY, Lou CH, Li Y, Ding X, Yu XY, Yang GM, Xu $D Q$, Jiang $L H$, Zhang $X$, Ye $L H$, Cai $B C$. Investigation on the morphological protective effect of 5-hydroxymethylfurfural extracted from wineprocessed Fructus corni on human L02 hepatocytes. J Ethnopharmacol. 2010;130:424-8.

53. Jiang ZQ, Ma YX, Li MH, Zhan XQ, Zhang X, Wang MY. 5-Hydroxymethylfurfural protects against ER stress-induced apoptosis in GalN/TNF-ainjured L02 hepatocytes through regulating the PERK-elF2a signaling pathway. Chin J Nat Med. 2015;13:896-905.

54. Park CH, Noh JS, Tanaka T, Roh SS, Lee JC, Yokozawa T. Polyphenol isolated from Corni Fructus, 7-O-galloyl-D-sedoheptulose, modulates advanced glycation endproduct-related pathway in type 2 diabetic $\mathrm{db} / \mathrm{db}$ mice. Arch Pharmacal Res. 2015:38:1270-80.

55. Lee NH, Seo CS, Lee HY, Jung DY, Lee JK, Lee JA, Song KY, Shin HK, Lee MY, Seo YB, Kim H, Ha H. Hepatoprotective and antioxidative activities of Cornus officinalis against acetaminophen-induced hepatotoxicity in mice. Evid Based Complement Altern Med. 2012;2012:1-8.

56. Sun H, Li L, Zhang A, Zhang N, Lv H, Sun W, Wang X. Protective effects of sweroside on human MG-63 cells and rat osteoblasts. Fitoterapia. 2013:84:174-9.
57. Kim JY, Kim YK, Choi MK, Oh J, Kwak HB, Kim JJ. Effect of Cornus Officinalis on receptor activator of nuclear factor-kappaB ligand (RANKL)-induced osteoclast differentiation. J Bone Metab. 2012:19:121.

58. An YA, Hwang JY, Lee JS, Kim YC. Cornus officinalis methanol extract upregulates melanogenesis in melan-a cells. Toxicol Res. 2015;31:165-72.

59. Liu X, Zeng YQ, Liang YZ, Zou C, Liu H, Qiu F, Liang CL, Jin XW, Su ZR, Dai Z. Medicinal herbs Fructus corni and Semen cuscutae suppress allograft rejection via distinct immune mechanisms. Oncotarget. 2016;7:35680.

60. Cho K, Lee HJ, Lee SY, Woo H, Lee MN, Seok JH, et al. Oleanolic acid and ursolic acid derived from Cornus officinalis Sieb. et Zucc. suppress epidermal growth factor- and phorbol ester-induced MUC5AC mucin production and gene expression from human airway epithelial cells. Phytother Res. 2011;25:760-4.

61. Kim SH, Kim BK, Lee YC. Effects of Corni fructus on ovalbumin-induced airway inflammation and airway hyper-responsiveness in a mouse model of allergic asthma. J Inflamm. 2012;9:9.

62. Kang DG, Choi DH, Lee JK, Lee YJ, Moon MK, Yang SN, Kwon TO, Kwon JW, Kim JS, Lee HS. Endothelial NO/cGMP-dependent vascular relaxation of cornuside isolated from the fruit of Cornus officinalis. Planta Med. 2007:73:1436-40.

63. Song JH, Park K, Shim A, Kwon BE, Ahn JH, Choi YJ, Kim JK, Yeo SG, Yoon K, $\mathrm{Ko} \mathrm{HJ}$. Complete sequence analysis and antiviral screening of medicinal plants for human Coxsackievirus A16 isolated in Korea. Osong Public Health Res Perspect. 2015;6:52-8.

64. Wu HZ. The clinical effect of Jinkui Shenqi pill on type 2 diabetes. Pharmacol Clin Chin Mater Med. 2013;29:191-3 (in Chinese).

65. Liu ZW. Curative effect valuation on Jingui Senqi pill in the treatment of diabetic nephropathy. Chin J Basic Med Tradit Chin Med. 2014;20(821-2):31.

66. Li X, Li Y. Clinical study on Liuwei Dihuang pills combined with liraglutide and metformin in treatment of type 2 diabetes mellitus. Drugs Clin. 2016;31:1146-50 (in Chinese)

67. He K, Zhu LH, Lu XW. Clinical observation of Liuwei Dihuang pills combined with metformin in the treatment of type 2 diabetes. Chin Tradit Pat Med. 2016:38:50-2.

68. Menzies FM, Fleming A, Rubinsztein DC. Compromised autophagy and neurodegenerative diseases. Nat Rev Neurosci. 2015;16:345-57.

69. Nah J, Yuan J, Jung YK. Autophagy in neurodegenerative diseases: from mechanism to therapeutic approach. Mol Cells. 2015;38:381-9.

70. Zhou ZY. Chinese internal medicine. Beijing: China Press of Traditional Chinese Medicine; 2003. p. 157, 176, 183, 308, 316, 327 (in Chinese)

71. Lin SK, Yan SH, Lai JN, Tsai TH. Patterns of Chinese medicine use in prescriptions for treating Alzheimer's disease in Taiwan. Chin Med. 2016;11:12.

72. Yeung WF, Chung KF, Zhang NL, Zhang SP, Yung KP, Chen PX, Ho YY. Identification of Chinese medicine syndromes in persistent insomnia associated with major depressive disorder: a latent tree analysis. Chin Med. 2016;11:4.

73. Cai H, Cao G, Cai B. Rapid simultaneous identification and determination of the multiple compounds in crude Fructus Corni and its processed products by HPLC-MS/MS with multiple reaction monitoring mode. Pharm Biol. 2013;51:273-8.

74. Zhang YE, Liu EH, Li HJ, Li P. Chemical constituents from the fruit of Cornus officinalis. Chin J Nat Med. 2009;7:365-7 (in Chinese)

75. Han SY, Pan Y, Ding G, Cai BC. Application of 1H-NMR and 13C-NMR spectra in the structure identification of iridoids from Cornus officinalis. Chin Arch Tradit Chin Med. 2004:22:56-9 (in Chinese)

76. Park JY, Han AR, Kil YS, Kang U, Kim SH, Nam SJ, Seo EK. A new secoiridoid glycoside from the fruits of Cornus officinalis (Cornaceae). Nat Prod Res. 2016:30:1504-10.

77. He J, Ye XS, Wang XX, Yang YN, Zhang PC, Ma BZ, Zhang WK, Xu JK. Four new iridoid glucosides containing the furan ring from the fruit of Cornus officinalis. Fitoterapia. 2017;120:136-41.

78. Han SY, Pan Y, Yang GM, Cai BC. Research on components of Cornus officinalis extracted by supercritical carbon dioxide. Zhongguo Zhong Yao Za Zhi. 2003:28:1148-50, 83 (in Chinese)

79. Kim DK, Kwak JY. A furan derivative from Comus officinalis. Arch Pharm Res. 1998;21:787-9.

80. Xie X, Wang R, Shi Y. Chemical constituents from the fruits of Cornus officinalis. Biochem Syst Ecol. 2012;45:120-3. 
81. Yang L, Wang Z, Huang L. Isolation and structural characterization of a polysaccharide FCAP1 from the fruit of Cornus officinalis. Carbohydr Res. 2010;345:1909-13.

82. Wang LL, Zhang T, Chen SQ, Shang CL. Study on the correlation between the quality of Cornus officinalis and the contents of the inorganic elements in the planting soil. Zhong Yao Cai. 2011;34:1167-72 (in Chinese).

83. Hsu JH, Wu YC, Liu IM, Cheng JT. Release of acetylcholine to raise insulin secretion in Wistar rats by oleanolic acid, one of the active principles contained in Cornus officinalis. Neurosci Lett. 2006:404:112-6.
84. Gu H, Jiang Z, Wang M, Jiang H, Zhao F, Ding X, Cai B, Zhan Z. 5-Hydroxymethylfurfural from wine-processed Fructus corni inhibits hippocampal neuron apoptosis. Neural Regen Res. 2013;8:2605-14.

85. Zhang QC, Zhao Y, Bian HM. Antiplatelet activity of a novel formula composed of malic acid, succinic acid and citric acid from Cornus officinalis fruit. Phytother Res. 2013;27:1894-6.
Ready to submit your research? Choose BMC and benefit from:

- fast, convenient online submission

- thorough peer review by experienced researchers in your field

- rapid publication on acceptance

- support for research data, including large and complex data types

- gold Open Access which fosters wider collaboration and increased citations

- maximum visibility for your research: over $100 \mathrm{M}$ website views per year

At BMC, research is always in progress.

Learn more biomedcentral.com/submissions 